\title{
25. Sr-ISOTOPIC EVIDENCE FOR LEAKAGE OF PORE WATER FROM CLAY-SILT CONFINING UNITS TO THE ATLANTIC CITY 800-FOOT SAND, ATLANTIC CITY, NEW JERSEY ${ }^{1}$
}

\author{
Zoltan Szabo, ${ }^{2}$ A.A. Pucci, Jr., ${ }^{3,4}$ and M.D. Feigenson ${ }^{5}$
}

\begin{abstract}
The evolution of water quality in confined aquifers in the New Jersey Coastal Plain may be affected by leakage of pore water from the adjacent confining units. We investigated the distribution and sources of solutes, particularly Sr, in pore water mechanically extracted from clay-silt core samples collected from depths of 552-840 ft (168-256 m) in the lower Miocene Kirkwood Formation at Atlantic City, New Jersey (Ocean Drilling Program Leg 150X). The sampled sediments consist of thin clay-silt stringers in the upper part of the Atlantic City 800-ft sand, a major aquifer, and the massive clay-silt units above and below it. The distribution of $\mathrm{Sr}$ and the ratio of ${ }^{87} \mathrm{Sr}$ to ${ }^{86} \mathrm{Sr}$ in the pore water and adjacent shell material were used to identify the possible sources of, and physical processes that may affect the distribution of, $\mathrm{Sr}$ in the pore water.

Concentrations of $\mathrm{Sr}$ in 14 pore-water samples from the clay-silt unit above the aquifer and the clay-silt interbeds in the upper part of the aquifer ranged from 2.74 to $28.19 \mu \mathrm{M} / \mathrm{L}$; those in the four pore-water samples from the clay-silt unit below the aquifer ranged from 0.52 to $7.30 \mu \mathrm{M} / \mathrm{L}$. Concentrations of $\mathrm{Sr}$ in the samples varied with depth but correlated strongly with pore-water concentrations of $\mathrm{Ca}, \mathrm{Mg}, \mathrm{Na}$, and $\mathrm{SO}_{4}$. Cation-exchange processes may be responsible, in part, for the lower concentrations of $\mathrm{Sr}, \mathrm{Ca}$, and $\mathrm{Mg}$ in pore water from the clay-silt unit below the aquifer than in that above the aquifer.

${ }^{87} \mathrm{Sr} /{ }^{86} \mathrm{Sr}$ values in 11 samples of aragonitic mollusk shells (bearing no visible evidence of recrystallization) collected from depths in the clay-silt unit similar to those from which the pore-water samples were collected ranged from 0.708468 to 0.708713 , and decreased ( $\mathrm{Sr}$ in the shells was less radiogenic) with depth. This trend is consistent with the decrease in the ${ }^{87} \mathrm{Sr} /{ }^{86} \mathrm{Sr}$ value in seawater through time during the early Miocene. The ${ }^{87} \mathrm{Sr} /{ }^{86} \mathrm{Sr}$ values in 12 pore-water samples from the studied stratigraphic interval ranged from 0.708257 to 0.708527 and also decreased with depth. The Sr-isotope ratios in the pore water were lower than those in the shell material from nearby or adjacent sediments for all samples but one. Because the only known source of $\mathrm{Sr}$ with an isotope ratio this low is shell material from sediments deeper than the strata from which the pore-water samples were collected (including pre-Miocene stratigraphic units), the isotope ratio in the pore-water samples from the lower Miocene claysilt units may result from upward movement of pore water into lower Miocene strata through geologic time, which could create the observed difference in $\mathrm{Sr}$ isotope ratios between the pore water and shells.
\end{abstract}

\section{INTRODUCTION}

The evolution of water quality in confined aquifers of the Atlantic Coastal Plain results in the dominance of $\mathrm{Na}$ - and $\mathrm{HCO}_{3}$-type waters downdip. It has been hypothesized that this trend may partly be the result of leakage or diffusion of $\mathrm{SO}_{4}$-enriched pore water from the adjacent confining units (Chapelle and McMahon, 1991). The Atlantic Coastal Plain in the Eastern United States, of which the New Jersey Coastal Plain is a part, is a seaward-dipping wedge of unconsolidated sediments that range in age from Cretaceous to Holocene. These sediments consist of clay, silt, sand, and gravel deposited in alternating sequences of high- and low-permeability strata that represent interfingering deltaic and marine-shelf deposits. The thick sand units found between silt or clay units typically are confined aquifers. In several of these aquifers in New Jersey, such as the Piney Point aquifer (Harriman and Sargent, 1985) and the Atlantic City 800-ft sand (Barton et al., 1993), the water is increasingly dominated by $\mathrm{Na}$ and $\mathrm{HCO}_{3}$ in the downdip direction (toward the southernmost part of New Jersey).

The Atlantic City $800-\mathrm{ft}$ sand is a nearly 100 -ft-thick $(30 \mathrm{~m}$ ) layer of coarse- to medium-grained sand and, in places, gravel enclosed in

${ }^{1}$ Miller, K.G., and Snyder, S.W. (Eds.), 1997. Proc. ODP, Sci. Results, 150X: College Station, TX (Ocean Drilling Program).

${ }^{2}$ U.S. Geological Survey, 810 Bear Tavern Rd., Suite 206, W. Trenton, NJ 086280099, U.S.A. zszabo@usgs.gov U.S.A.

${ }^{3}$ Lafayette College, Civil and Environmental Engineering, Easton, PA 18042-1775,

${ }^{4}$ Present address: P.O. Box 34, Erwinna, PA 18920, U.S.A.

${ }^{5}$ Rutgers University, Department of Geological Sciences, Piscataway, NJ 088551179, U.S.A. clay-silt units near the base of the lower Miocene Kirkwood Formation (Zapecza, 1989). The Kirkwood Formation crops out over a broad area of the southwestern New Jersey Coastal Plain (Fig. 1) and, following the regional trend, dips to the southeast. The base of the sand and gravel unit that forms the Atlantic City $800-\mathrm{ft}$ sand is about $800 \mathrm{ft}(240 \mathrm{~m})$ below land surface beneath the barrier islands in eastern Atlantic County, NJ.

Results of a recent study of the quality of pore water in finegrained sediments in the New Jersey Coastal Plain show elevated concentrations of $\mathrm{SO}_{4}, \mathrm{Ca}$, and $\mathrm{Na}$ (Pucci et al., 1992); these results agree with the findings of Chapelle and McMahon (1991) for claysilt confining units in other parts of the Atlantic Coastal Plain. The chemistry of water in the confined aquifers in the New Jersey Coastal Plain, such as the Atlantic City 800-ft sand, likely is affected if leakage of mineralized pore water from the confining units occurs. The results of a computer simulation of prepumping ground-water flow in the New Jersey Coastal Plain (Martin, in press) indicates that in the Atlantic City region water from pre-Miocene strata moves upward through the Atlantic City 800 -ft sand before it discharges to the Atlantic Ocean (Fig. 2).

Information on the distribution of solutes is needed to determine whether the solutes migrate within or through confining units and whether mineralogical variations in the sediments result in compositional variations in the pore water. An ongoing cooperative investigation by the U.S. Geological Survey, the New Jersey Department of Environmental Protection, Rutgers University, and Lafayette College is being conducted to evaluate the potential effects of confining-unit pore water on the quality of water in confined aquifers. The distribution and sources of solutes in the pore waters in the fine-grained units near the base of the lower Miocene Kirkwood Formation above and 


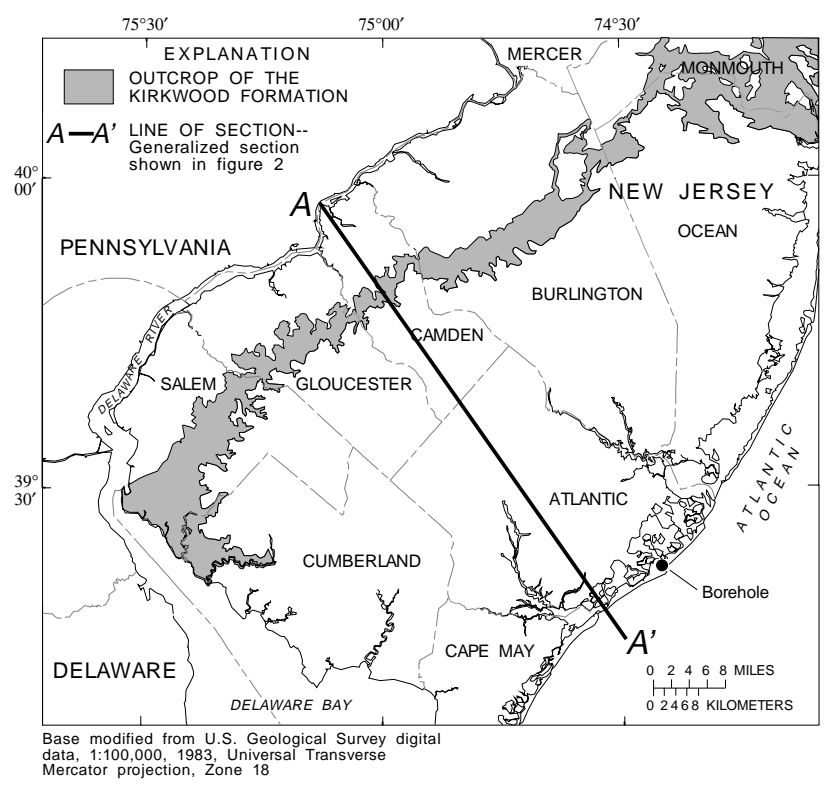

Figure 1. Location of the Leg 150X Atlantic City borehole; outcrop of the lower Miocene Kirkwood Formation; and generalized line of Section A-A' through the southern Coastal Plain of New Jersey.

below the Atlantic City 800-ft sand were studied as part of this investigation.

$\mathrm{Sr}$ is ideal for such a study because it is abundant in most rockforming minerals, including silicate and carbonate minerals (such as calcite or aragonite shell material), and because it is readily soluble. Furthermore, because the isotopes of $\mathrm{Sr}$ do not undergo observable fractionation during chemical processes (dissolution, precipitation, biologically mediated shell formation), and the ratio of two of the more common isotopes of $\mathrm{Sr}$, the ${ }^{87} \mathrm{Sr} /{ }^{86} \mathrm{Sr}$ value, varies greatly among different geologic materials, the isotope ratio of $\mathrm{Sr}$ in solution is an indicator of the source of the dissolved $\mathrm{Sr}$. The ${ }^{87} \mathrm{Sr} /{ }^{86} \mathrm{Sr}$ value has been used extensively to determine the source of $\mathrm{Sr}$ in pore water, the amount of water/rock interaction, and the hydrogeochemical processes in various geohydrologic environments, including shallow dilute ground water (Bishop et al., 1994; Stanley and Faure, 1979; Steuber et al., 1975), connate brines (Szabo, 1984; Stueber et al., 1984; Sunwall and Pushkar, 1979), and even pore water from deep-sea sediment (Elderfield and Gieskes, 1982; Hawkesworth and Elderfield, 1978). For example, the magnitude of the difference between the ${ }^{87} \mathrm{Sr} /{ }^{86} \mathrm{Sr}$ value in pore water (or carbonate minerals precipitated from pore water) and that in seawater is an indicator of the amount of chemical interaction between the pore water and silicate minerals in the sediment matrix. Determining the concentration and isotopic composition of $\mathrm{Sr}$ in the pore water in an individual confining unit in the Atlantic Coastal Plain and the isotopic composition of $\mathrm{Sr}$ in the primary Sr-bearing solid phase (sedimentary shell material) may provide similar information in this hydrogeologic setting. Therefore, an investigation was undertaken within the framework of the larger study to determine (1) the distribution of $\mathrm{Sr}$ in pore water in clay-silt confining units adjacent to the aquifer and (2) the possible sources of dissolved $\mathrm{Sr}$ from the isotopic composition of $\mathrm{Sr}$, to identify the chemical and transport processes that may affect the distribution of solutes in confining units.

Pore-water and shell-material samples were collected at regular intervals at depths of 552-840 ft $(168-256 \mathrm{~m})$ below land surface in a continuously cored borehole (Ocean Drilling Program Leg 150X) in Atlantic City, New Jersey (Fig. 1), in the clayey silt of the "lower" confining unit overlying the Atlantic City 800 -ft sand (as defined by
Miller et al., 1994), the composite confining unit underlying the aquifer, and interbedded silt stringers in the upper part of the aquifer (Fig. 3). (The "lower" confining unit of Miller et al. [1994] is equivalent to the bottom half of the "confining unit above the Atlantic City $800-\mathrm{ft}$ sand" as described by Zapecza [1989] and was not included as a separate confining unit in the model of Martin [in press].) Pore-water samples were mechanically extracted from the clay-silt sediments for chemical analysis (19 samples) and for determination of the ${ }^{87} \mathrm{Sr} /{ }^{86} \mathrm{Sr}$ values (12 samples). In addition, the ${ }^{87} \mathrm{Sr} /{ }^{86} \mathrm{Sr}$ values in 11 shell samples from about the same sampled interval (559-869 ft [170.4-264.9 $\mathrm{m}]$ ) were determined. This report summarizes the variations in the concentration of $\mathrm{Sr}$ in the pore-water samples and the ${ }^{87} \mathrm{Sr} /{ }^{86} \mathrm{Sr}$ value in the pore-water and shell-material samples with depth. Possible sources of $\mathrm{Sr}$ and geochemical processes that affect its concentration in pore water are considered, and the relation of the ${ }^{87} \mathrm{Sr} /{ }^{86} \mathrm{Sr}$ value in the pore water to the regional prepumping ground-water-flow system (Fig. 2). as simulated by Martin (in press) are discussed.

\section{Use of Strontium Isotopes as Stratigraphic Dating Tools and Indicators of Sediment-Water Interaction}

Peterman et al. (1970) demonstrated the use of original, unreplaced calcium carbonate fossil shells in determining the systematic variation of the ${ }^{87} \mathrm{Sr} /{ }^{86} \mathrm{Sr}$ value in seawater through time. Calcium carbonate minerals in the shells of marine animals are precipitated from seawater; the $\mathrm{Sr}$ in these minerals is in isotopic equilibrium with that in seawater for most species, including mollusks. Unreplaced or unaltered skeletal aragonite (or, for some species, calcite) or shells of these marine animals found as fossils, therefore, contain ${ }^{87} \mathrm{Sr} /{ }^{86} \mathrm{Sr}$ in the same ratio as that found in the seawater from which they were precipitated. The ratio of ${ }^{87} \mathrm{Sr} /{ }^{86} \mathrm{Sr}$ in the ocean, and, thus, in marine shell material, is homogeneous at any given time because the residence time of $\mathrm{Sr}$ in the ocean is long compared to the mixing time of the ocean (Faure, 1982), and because the concentration of Sr in seawater is high relative to that in river-water input, thereby limiting local variability.

The ratio of ${ }^{87} \mathrm{Sr} /{ }^{86} \mathrm{Sr}$ in shell material, therefore, can be used as a dating tool in stratigraphic studies. Once the age of a reference stratigraphic section is calibrated to the time scale by paleontological, paleomagnetic, or isotopic dating techniques, the ratio of ${ }^{87} \mathrm{Sr} /{ }^{86} \mathrm{Sr}$ in shell material from other stratigraphic sections, representing the ratio of ${ }^{87} \mathrm{Sr} /{ }^{86} \mathrm{Sr}$ in the seawater from which the sediment was deposited, can be correlated to the time of deposition.

The ${ }^{87} \mathrm{Sr} /{ }^{86} \mathrm{Sr}$ dating technique is especially sensitive for lower to middle Miocene strata, because the rapid change of the marine ${ }^{87} \mathrm{Sr} /$ ${ }^{86} \mathrm{Sr}$ value during this epoch allows for the differentiation between small intervals of time. The rate of change in the marine ${ }^{87} \mathrm{Sr} /{ }^{86} \mathrm{Sr}$ value was especially rapid in the Tertiary Period, rising from about 0.70760 at the beginning to the current value of 0.70906 . The ratio rose most rapidly in the Oligocene and Miocene Epochs (Oslick et al., 1994; Sugarman et al., 1993; Faure, 1982). The Sr-isotope stratigraphy of the lower Miocene Kirkwood Formation in southern New Jersey has been documented by Sugarman et al. (1993), Miller and Sugarman (1995), and Sugarman et al. (Chapter 12, this volume).

If the $\mathrm{Sr}$ in the pore water is derived from either the original seawater entrapped, with a unique ${ }^{87} \mathrm{Sr} /{ }^{86} \mathrm{Sr}$ value, in the sediment, or the calcium carbonate minerals or shells precipitated from seawater during deposition of the sediment, then the isotope ratio of $\mathrm{Sr}$ in the pore water will reflect that in seawater at the time of deposition. Seawater entrapped in geologic strata is assumed to mix, through time, with recharging freshwater (freshwater typically contains minimal $\mathrm{Sr}$ and, hence, has little effect on the ${ }^{87} \mathrm{Sr} /{ }^{86} \mathrm{Sr}$ value in the mixture) to form the current interstitial fluid. As the pore water interacts with the silicate minerals in the sediment matrix, the ${ }^{87} \mathrm{Sr} /{ }^{86} \mathrm{Sr}$ value of the water generally tends to increase ( $\mathrm{Sr}$ in the water becomes more radiogenic) because most primary felsic silicate minerals, such as K-feldspar, and 


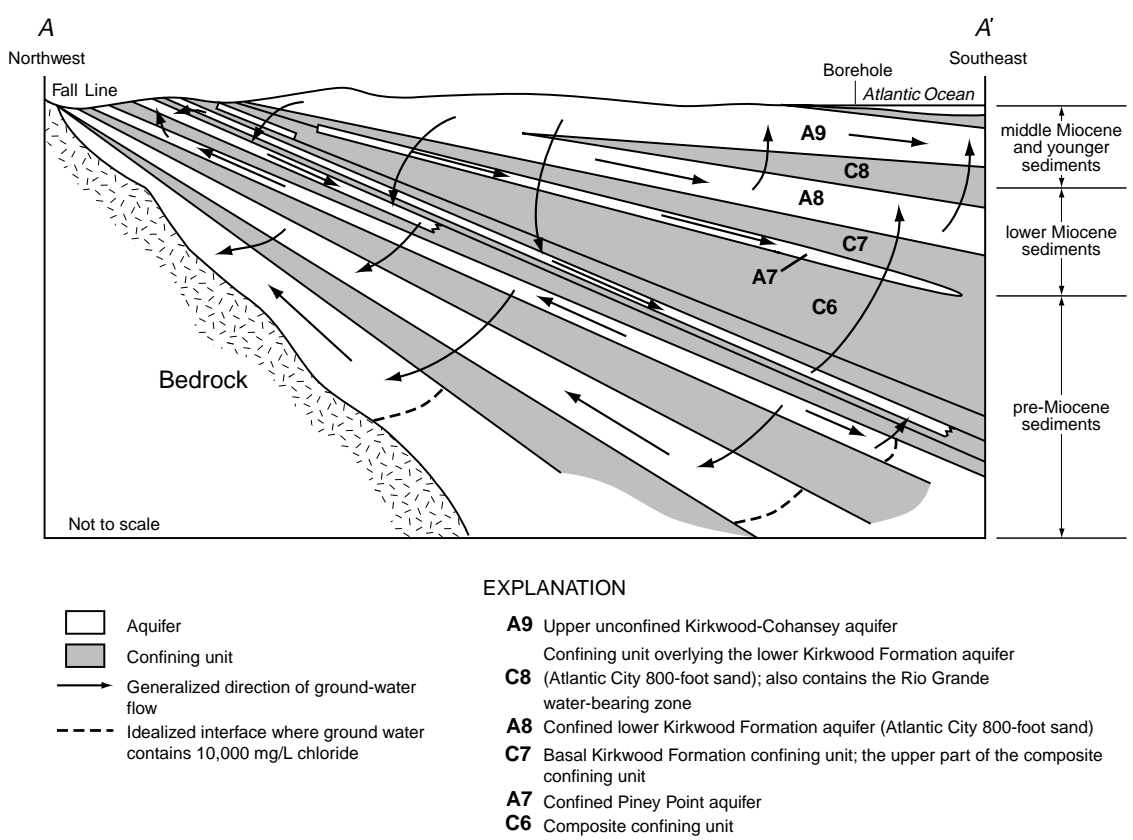

Figure 2. Generalized representation of simulated prepumping flow in a hydrogeologic section through the southern Coastal Plain of New Jersey (modified from Martin, in press, fig. 74; section-line location shown in Fig. 1). primary (detrital) and secondary (diagenetic) clay minerals are strongly enriched in ${ }^{87} \mathrm{Sr}$ relative to seawater (Table 1 ). Through time, therefore, the ${ }^{87} \mathrm{Sr} /{ }^{86} \mathrm{Sr}$ value in the evolving pore water tends to become similar to that in the minerals in the sedimentary matrix from which the Sr in solution is primarily derived (Szabo and Faure, 1987; Stanley and Faure, 1979). The magnitude of the change in the ratio in the pore water relative to that in the primary seawater is an indicator of the degree to which the sedimentary matrix is enriched in radiogenic ${ }^{87} \mathrm{Sr}$, the amount of chemical interaction between the pore water and mineral phases in the sediment matrix, the amount of mixing with fluids with different ${ }^{87} \mathrm{Sr} /{ }^{86} \mathrm{Sr}$ values, or all of the above. Some examples of reported ${ }^{87} \mathrm{Sr} /{ }^{86} \mathrm{Sr}$ values in excess of 0.725 in various detrital or authigenic silicate minerals or in clastic rocks are given in Table 1; these include ratios in detrital K-feldspar as high as 0.727 (Szabo and Faure, 1987), in shale as high as 0.745 (Stueber et al., 1975; Szabo and Faure, 1987), and in plagioclase-free arkose as high as 0.749 (Stanley and Faure, 1979).

Shallow ground water, deep ground water, and deep brines have all been shown to contain more radiogenic Sr than seawater at the time of deposition. Stueber et al. (1975) and Fisher and Stueber (1976) report ${ }^{87} \mathrm{Sr} /{ }^{86} \mathrm{Sr}$ values as high as 0.713 and 0.716 in shallow ground water from shale, whereas Sunwall and Pushkar (1979) report ratios of about 0.7103 for deep brine (Table 1 ).

Secondary minerals precipitated from pore water, such as calcite found as cement or grain coatings, preserve the ${ }^{87} \mathrm{Sr} /{ }^{86} \mathrm{Sr}$ value of the pore water at the time of secondary-mineral formation because isotopic fractionation of $\mathrm{Sr}$ during precipitation of secondary minerals from pore water is also negligible (Faure, 1982). The ${ }^{87} \mathrm{Sr} /{ }^{86} \mathrm{Sr}$ value in secondary minerals, therefore, is a function solely of that in the pore water from which the mineral precipitated (Veizer, 1983). The ${ }^{87} \mathrm{Sr} /{ }^{86} \mathrm{Sr}$ value in calcium carbonate-mineral cements, mineral coatings, or micritic matrix precipitated from pore water enriched in ${ }^{87} \mathrm{Sr}$ relative to seawater is higher than that in unaltered carbonate shells that still have the same ${ }^{87} \mathrm{Sr} /{ }^{86} \mathrm{Sr}$ value as the seawater from which they were precipitated (Popp et al., 1986). Reported ${ }^{87} \mathrm{Sr} /{ }^{86} \mathrm{Sr}$ values in secondary calcite cements in various clastic rocks can exceed 0.712 (Table 1). In extreme cases of silicate-mineral dissolution or replacement, such as nearly complete replacement of K-feldspar grains by carbonate cement (Szabo, 1984), both the pore water and the carbonate cement formed from it may be highly enriched in ${ }^{87} \mathrm{Sr}$ relative to seawater; the ${ }^{87} \mathrm{Sr} /{ }^{86} \mathrm{Sr}$ value in the secondary calcite formed in such a situation was found to be as high as 0.714 (Szabo and Faure, 1987). The magnitude of the difference between the ${ }^{87} \mathrm{Sr} /{ }^{86} \mathrm{Sr}$ value in pore water or carbonate minerals precipitated from pore water and that in seawater is, therefore, an indicator of the amount of chemical interaction between the pore water and the silicate minerals in the sediment matrix.

\section{METHODS}

Nineteen 1-ft $(0.3 \mathrm{~m})$ segments of clay-silt sediment were cut with a sharp knife from the most intact parts of core sections from the lower Miocene Kirkwood Formation collected from the borehole at Atlantic City, N.J. The sediment samples were collected at approximately $10-\mathrm{ft}(3 \mathrm{~m})$ intervals from below land surface depths of $552-651 \mathrm{ft}$ (168.2-198.4 m; 11 pore-water samples analyzed for $\mathrm{Sr}$ concentration, ${ }^{87} \mathrm{Sr} /{ }^{86} \mathrm{Sr}$ determined for eight samples); 681-705 ft (207.6$214.9 \mathrm{~m}$; three pore-water samples analyzed for $\mathrm{Sr}$ concentration, ${ }^{87} \mathrm{Sr} /{ }^{86} \mathrm{Sr}$ determined for one sample); and 819-840 ft (249.6-256.0 m; four pore-water samples analyzed for $\mathrm{Sr}$ concentration, ${ }^{87} \mathrm{Sr} /{ }^{86} \mathrm{Sr}$ determined for two samples; Fig. 3). The pore-water samples are representative of water in the lower confining unit overlying the Atlantic City 800-ft sand, an interbedded clay-silt unit in the uppermost part of the aquifer, and the composite confining unit underlying the aquifer, respectively. In addition, one sediment sample was collected from the isolated clay-silt stringer at a depth of $736 \mathrm{ft}(224.3 \mathrm{~m})$ in the Atlantic City 800-ft sand for pore-water extraction and determination of $\mathrm{Sr}$ concentration and the ${ }^{87} \mathrm{Sr} /{ }^{86} \mathrm{Sr}$ value.

The sediment samples were stored under an $\mathrm{N}_{2}$ atmosphere in an anaerobic jar (Difco 1950-30-2) at a temperature of $4^{\circ} \mathrm{C}$ until the pore water was extracted about 1-4 weeks later. Pore-water samples were mechanically extracted from the silts at a maximum pressure of 9000 psi; details are given by Pucci et al. (Chapter 24, this volume). Deionized water was passed through the extraction equipment and used as the process blank sample. The result of the analysis of this sample indicates minimal contamination with $\mathrm{Sr}$ during sample processing (maximum of $0.057 \mu \mathrm{M} / \mathrm{L}$ ). The $\mathrm{pH}$ of the pore water was determined in a 1- to $2-\mathrm{mL}$ sample aliquot as soon as possible after extraction with a narrow-tipped glass probe. 


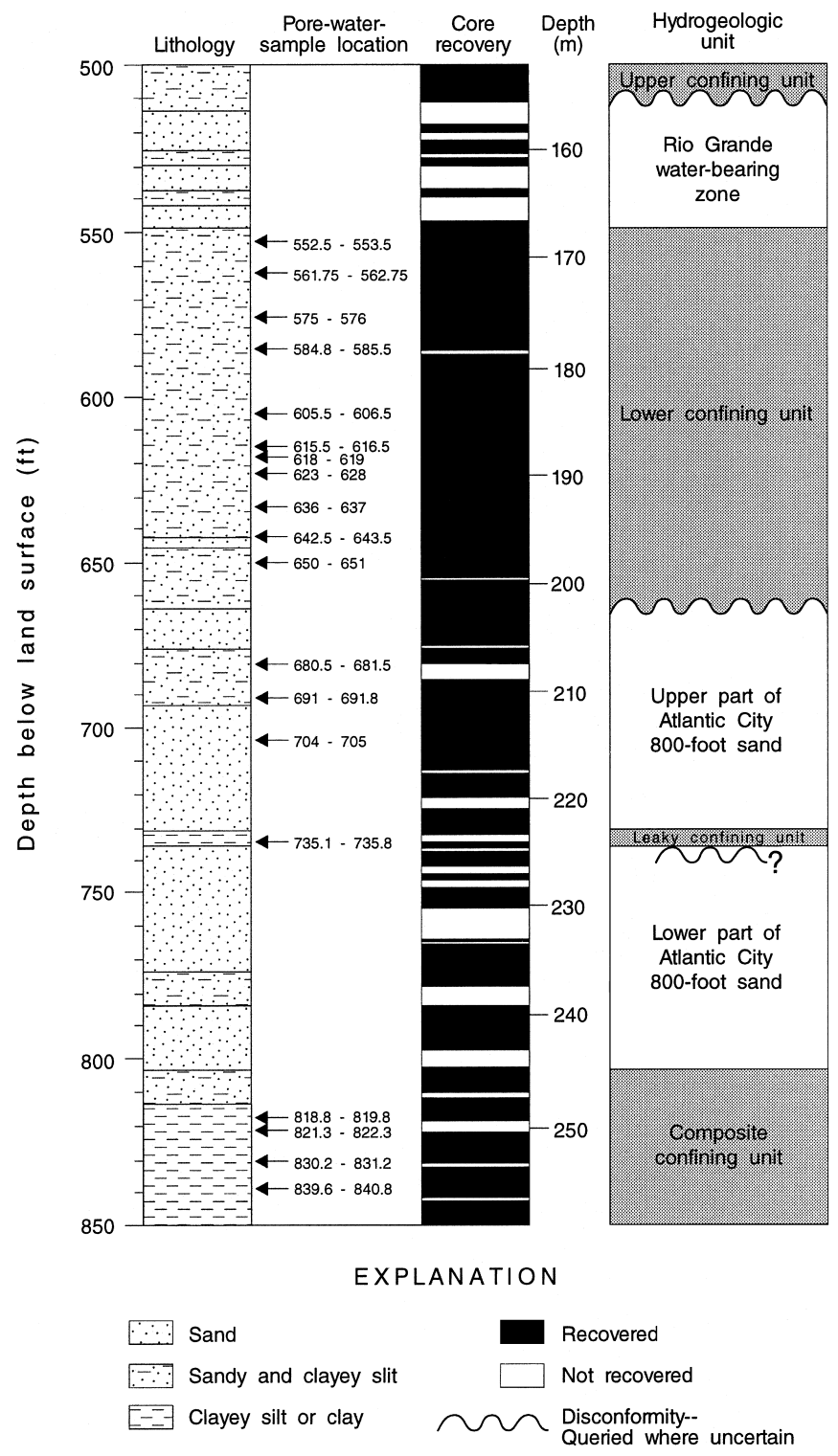

Figure 3. Lithology, pore-water sample locations, core recovery, and hydrogeologic units, lower Miocene Kirkwood Formation, Leg 150X Atlantic City borehole (modified from Miller, et al., 1994).

Concentrations of $\mathrm{Sr}$ and major cations $(\mathrm{Ca}, \mathrm{Mg}$, and $\mathrm{Na})$ in the pore water were determined by inductively coupled plasma-atomic emission spectroscopy (ICP-AES) on $5 \mathrm{~mL}$ of sample diluted 1:1 with deionized water. Concentrations of $\mathrm{SO}_{4}$ were determined by ion chromatography on $1 \mathrm{~mL}$ of sample diluted 1:200 with deionized water. One $\mathrm{mL}$ of undiluted sample each was used to determine concentrations of $\mathrm{Cl}$ by colorimetry and of DIC (dissolved inorganic carbon) by infrared spectrometry. The ${ }^{87} \mathrm{Sr} /{ }^{86} \mathrm{Sr}$ values were determined by mass spectrometry (as described below) on 2 to $5 \mathrm{~mL}$ of undiluted pore-water sample.

The ${ }^{87} \mathrm{Sr} /{ }^{86} \mathrm{Sr}$ values in calcareous mollusk shells from shell beds in clay silt, silt, or silty sand collected from the Kirkwood Formation, as well as those in shells collected from pre- and post-Miocene strata cored at Atlantic City, also were determined by mass spectrometry after dissolution of the shell material. These results are described by Miller et al. (1994) and Sugarman et al. (Chapter 12, this volume). Eleven samples of shell material were collected from about the same depth intervals as the pore-water samples: four were from the lower confining unit, three were from the clay-silt unit in the upper part of the Atlantic City 800-ft sand, and four were from the composite confining unit. The depths from which the pore-water and shell-material samples were obtained did not always coincide because pore-water samples were collected only from unfractured, competent silt or clay, whereas shell beds commonly were sandy. The ${ }^{87} \mathrm{Sr} /{ }^{86} \mathrm{Sr}$ values of the silicate minerals in the clay-silt unit were not determined, but were assumed to be on the order of $0.707-0.710$ on the basis of Biscaye's (1972) work on estuarine and shelf sediments and that of Dasch (1969) on shelf and deep-sea sediments.

Because Sugarman et al. (1993) found that shells from the Kirkwood Formation were completely aragonitic, the shells or shell-hash materials selected for analysis were inspected only visually for evidence of corrosion or diagenetic alteration. Neither recrystallization of shell material nor coating of shell material with a drusy or micritic crust was observed. A piece about $5 \mathrm{~mm}$ in diameter was taken from the most pristine part of the shell, ultrasonically cleaned in distilled water for 5-10 s, crushed, and dissolved in $1.5 \mathrm{~N} \mathrm{HCl}$.

Ion-exchange techniques were used to separate $\mathrm{Sr}$ for isotopic analysis. The analyses were completed on a VG Sector mass spectrometer at Rutgers University. Intrarun precision was $+/-0.000008$, whereas interrun precision was about $+/-0.000026$ to 0.000030 . The ${ }^{87} \mathrm{Sr} /{ }^{86} \mathrm{Sr}$ value of reference Sample NBS 987 was determined at the Rutgers laboratory to be 0.710255 (Oslick et al., 1994).

Nonparametric Spearman rank correlation analysis was used to evaluate the relations between concentrations of $\mathrm{Sr}$ and those of other selected dissolved constituents in the 14 uppermost pore-water samples (11 from the lower confining unit and three from clay/silt interbeds in the Atlantic City 800-ft sand); correlations significant at a $90 \%$ confidence level are reported. Nonparametric statistics were used because the pore-water concentration data were not normally distributed. The ion-activity product of ions in solution was calculated with the geochemical speciation program SOLMINEQ.88 (Kharaka et al., 1988) to determine the degree to which pore-water samples were saturated with mineral phases, such as carbonates, present in the Kirkwood Formation.

Linear regression was completed for the relation between $\mathrm{Sr}$ isotope ratios and depth in both pore water and shell material from 559 to $661 \mathrm{ft}$ (170.4-201.5 m), which corresponds to the lower confining unit, and in pore water from 559 to $681 \mathrm{ft}$ (170.4-207.6 m). The $95 \%$ confidence intervals were computed about the slopes (Dowdy and Wearden, 1983), which were recalculated by using standardized data, in order to evaluate with the Student's $t$-test whether the difference in the rate of change of the Sr-isotope ratios with depth between pore-water and shell-material samples was statistically significant. Linear regression also was used to describe the relation between concentrations of strongly correlated pore-water constituents.

\section{RESULTS}

Concentrations of $\mathrm{Sr}$ in the 14 uppermost pore-water samples ranged from 2.80 to $28.14 \mu \mathrm{M} / \mathrm{L}$, whereas those in the four porewater samples from the composite confining unit below the aquifer ranged from 1.31 to $7.27 \mu \mathrm{M} / \mathrm{L}$ (Table 2). The highest concentrations of dissolved $\mathrm{Sr}$ were in pore water extracted from sediments collected near the top of the lower confining unit. Pore-water concentrations of Sr generally decreased with depth, but were highly variable with a series of sharp peaks that increased in magnitude toward the top of the lower confining unit (Fig. 4).

The ${ }^{87} \mathrm{Sr} /{ }^{86} \mathrm{Sr}$ values in the 11 shell samples from shell-hash beds in the clay-silt sediment in the lower half of the Kirkwood Formation ranged from 0.708468 to 0.708713 . The ratios decreased (the $\mathrm{Sr}$ in the shells was less radiogenic) relatively smoothly with depth (Fig. 
Table 1. Typical ${ }^{87} \mathrm{Sr} /{ }^{86} \mathrm{Sr}$ values in silicate minerals, shallow ground water, deep brine, and secondary calcite cements.

\begin{tabular}{|c|c|c|c|}
\hline $\begin{array}{l}{ }^{87} \mathrm{Sr} /{ }^{86} \mathrm{Sr} \text { value, } \\
\text { silicate mineral or matrix }\end{array}$ & $\begin{array}{l}{ }^{87} \mathrm{Sr} /{ }^{86} \mathrm{Sr} \text { value, } \\
\text { associated water }\end{array}$ & $\begin{array}{c}{ }^{87} \mathrm{Sr} /{ }^{86} \mathrm{Sr} \text { value, associated } \\
\text { secondary calcite }\end{array}$ & Source \\
\hline $0.7071-0.71849$, shale & $0.7071-0.7105^{*}$ & $0.7074-0.7081$ & Stueber et al. (1984) \\
\hline ND, sandstone & $0.7092-0.7143^{*}$ & ND & Sunwall and Pushkar (1979) \\
\hline $0.7027-0.705$, volcanic detritus & 0.70694-0.70926 & ND & Elderfield and Gieskes (1982) \\
\hline 0.716 , continental (clayey) detritus & 0.70794-0.70924 & & \\
\hline $\mathrm{ND}$, shale & $0.7091-0.7166$ & ND & Fisher and Stueber (1976) \\
\hline ND, schist & $0.7099-0.7218$ & & \\
\hline $0.732-0.745$, shale & $0.7102-0.7131$ & ND & Stueber et al. (1975) \\
\hline $\mathrm{ND}$, basaltic volcanic sediment & $0.7045-0.7054$ & ND & Collerson et al. (1988) \\
\hline $\mathrm{ND}$, rhyolitic volcanic sediment & $0.7060-0.7118$ & & \\
\hline 0.7491 , arkose & ND & 0.7112 & Stanley and Faure (1979) \\
\hline 0.7102 , vitric sandstone & ND & 0.7103 & \\
\hline 0.7214-0.7271, K-feldspar & ND & $0.7090-0.7144$ & Szabo and Faure (1987) \\
\hline 0.7452 , shale & ND & ND & \\
\hline
\end{tabular}

Notes: $*$ brine. $\mathrm{ND}=$ not determined

Table 2. Chemical composition of pore water from clay-silt and Sr-isotope ratios in pore water and shells, lower Miocene Kirkwood Formation, Atlantic City borehole.

\begin{tabular}{|c|c|c|c|c|c|c|c|c|c|c|c|c|}
\hline $\begin{array}{l}\text { Sample } \\
\text { number }\end{array}$ & $\begin{array}{l}\text { Sample depth } \\
\text { (ft below } \\
\text { land surface) }\end{array}$ & $\mathrm{pH}$ & $\begin{array}{c}\text { Specific } \\
\text { conductance } \\
(\mu \mathrm{S} / \mathrm{cm})\end{array}$ & $\begin{array}{l}\text { Sulfate } \\
(\mathrm{mM} / \mathrm{L})\end{array}$ & $\begin{array}{c}\text { Dissolved } \\
\text { inorganic } \\
\text { carbon } \\
(\mathrm{mM} / \mathrm{L})\end{array}$ & $\begin{array}{l}\text { Chloride } \\
(\mathrm{mM} / \mathrm{L})\end{array}$ & $\begin{array}{l}\text { Calcium } \\
(\mathrm{mM} / \mathrm{L})\end{array}$ & $\begin{array}{l}\text { Magnesium } \\
(\mathrm{mM} / \mathrm{L})\end{array}$ & $\begin{array}{l}\text { Sodium } \\
(\mathrm{mM} / \mathrm{L})\end{array}$ & $\begin{array}{l}\text { Strontium } \\
(\mu \mathrm{M} / \mathrm{L})\end{array}$ & $\begin{array}{l}{ }^{87} \mathrm{Sr} /{ }^{86} \mathrm{Sr} \text {, } \\
\text { pore water }\end{array}$ & $\begin{array}{c}{ }^{87} \mathrm{Sr} /{ }^{86} \mathrm{Sr}, \\
\text { shells }\end{array}$ \\
\hline \multicolumn{13}{|c|}{ Lower confining unit } \\
\hline 1 & 553 & 7.8 & 2210 & 9.31 & 0.65 & 2.81 & $6.41 *$ & 1.81 & 4.17 & 28.14 & - & $0.708713^{\dagger}$ \\
\hline 2 & 562 & 8.0 & 1710 & 6.63 & 1.17 & 2.04 & $4.99 *$ & 1.36 & 3.35 & 21.32 & 0.708527 & $0.708668^{\ddagger}$ \\
\hline 3 & 575 & 8.3 & 1340 & 5.00 & 0.92 & 1.59 & $3.99 *$ & 1.07 & 2.78 & 16.06 & 0.708508 & - \\
\hline 4 & 585 & 8.3 & 1400 & 5.04 & 1.08 & 1.94 & $3.74 *$ & 1.15 & 3.13 & 17.45 & 0.708486 & - \\
\hline 5 & 606 & 8.0 & 470 & 1.00 & 0.83 & 2.07 & 0.92 & 0.29 & 2.09 & 4.09 & 0.708491 & 0.708656 \\
\hline 6 & 616 & 7.7 & 770 & 1.82 & 1.50 & 2.27 & $1.95^{*}$ & 0.62 & 2.48 & 8.43 & 0.708470 & - \\
\hline 7-A1 & 619 & 8.2 & 440 & 0.59 & 0.78 & 1.90 & 0.80 & 0.26 & 1.83 & 3.56 & - & - \\
\hline 7-B1 & 626 & 8.2 & 550 & 0.96 & 1.08 & 1.76 & $1.10^{*}$ & 0.35 & 2.17 & 4.91 & 0.708470 & - \\
\hline 7-B2 & 626 & 8.2 & - & 1.61 & 0.92 & 1.75 & $1.37 *$ & 0.41 & 2.22 & 6.05 & - & - \\
\hline 8 & 637 & 8.2 & 430 & 0.75 & 0.83 & 1.21 & $0.87 *$ & 0.28 & 1.61 & 3.67 & 0.708494 & - \\
\hline 9 & 643 & 8.6 & 1500 & 5.78 & 1.08 & 1.88 & $4.07 *$ & 1.23 & 3.48 & 18.02 & 0.708471 & 0.708672 \\
\hline 10 & 651 & 8.6 & 620 & 2.03 & 1.17 & 1.33 & $1.42 *$ & 0.45 & 2.21 & 6.17 & - & $\begin{array}{l}0.708640, \\
0.708494^{* *}\end{array}$ \\
\hline \multicolumn{13}{|c|}{ Silt stringers, upper part of the Atlantic City $800-\mathrm{ft}$ sand } \\
\hline 11 & 681 & 7.7 & 380 & 1.20 & 0.56 & 0.74 & 0.82 & 0.30 & 1.35 & 3.64 & 0.708434 & - \\
\hline 12 & 691 & 8.1 & 410 & 0.97 & 0.51 & 1.35 & 0.80 & 0.26 & 1.57 & 3.21 & - & - \\
\hline 13 & 705 & 8.2 & 320 & 0.75 & 0.72 & 0.57 & 0.65 & 0.20 & 1.30 & 2.80 & - & $0.708476^{\ddagger}$ \\
\hline 14 & 736 & 7.7 & 1000 & 4.11 & 0.35 & 0.96 & 2.47 & 0.91 & 2.39 & 10.72 & 0.708523 & - \\
\hline \multicolumn{13}{|c|}{ Composite confining unit } \\
\hline $15^{1}$ & 819 & 8.7 & 860 & 1.67 & 2.08 & 1.34 & $0.27 *$ & 0.13 & 7.61 & 1.31 & - & - \\
\hline 16 & 822 & 8.6 & 1630 & 4.90 & 2.25 & 1.94 & $0.95^{*}$ & 0.66 & 12.17 & 7.27 & 0.708353 & 0.708469 \\
\hline 17 & 831 & 8.8 & 720 & 0.88 & 2.08 & 2.21 & $0.21 *$ & 0.12 & 6.39 & 1.31 & - & 0.708468 \\
\hline 18 & 840 & 8.5 & 660 & 0.72 & 1.67 & 2.06 & 0.14 & 0.049 & 5.83 & 0.52 & 0.708527 & $0.708453^{\dagger \dagger}$ \\
\hline
\end{tabular}

Notes: $\mu \mathrm{S} / \mathrm{cm}=$ microsiemens per centimeter. $*=$ water sample saturated with respect to calcite. $-=$ no data. ${ }^{\dagger}=$ analyzed shell at a depth of $519.5 \mathrm{ft} .{ }^{\ddagger}=$ analyzed shells are offset from pore-water sample by $2-3 \mathrm{ft}$; see Miller et al. (1994) for exact location. ** = analyzed shell at a depth of $661 \mathrm{ft}$. ${ }^{\dagger \dagger}=$ analyzed shell at a depth of $854 \mathrm{ft}$. Isotope ratios in shells from Miller et al., 1994.

5). The ${ }^{87} \mathrm{Sr} /{ }^{86} \mathrm{Sr}$ values determined by Miller et al. (1994) in the 12 shell samples collected below $840 \mathrm{ft}(252 \mathrm{~m})$, predominantly from pre-Miocene stratigraphic units below the Kirkwood Formation, were significantly lower than those measured in the shell samples from the Kirkwood Formation (range 0.70778-0.70844) and also decreased relatively smoothly with depth (Fig. 5). This trend is consistent with the decrease through time in the ${ }^{87} \mathrm{Sr} /{ }^{86} \mathrm{Sr}$ value in seawater during these epochs, as has been demonstrated by Sugarman et al. (1993), Oslick et al. (1994), and Miller and Sugarman (1995).

The ${ }^{87} \mathrm{Sr} /{ }^{86} \mathrm{Sr}$ values in the 12 samples of pore water from the lower part of the Kirkwood Formation ranged from 0.708257 to 0.708527 and decreased (the $\mathrm{Sr}$ in the water was less radiogenic) relatively smoothly with depth, as did those in the shell material (Fig. 5), with two minor exceptions: the $\mathrm{Sr}$ in pore-water Samples 8 and 14 was more radiogenic than that in the pore water from the immediately overlying sediment (Fig. 5). In addition, ${ }^{87} \mathrm{Sr} /{ }^{86} \mathrm{Sr}$ values in Samples $4(585 \mathrm{ft}[178.3 \mathrm{~m}])$ and $5(606 \mathrm{ft}[184.7 \mathrm{~m}])$ could not be distinguished from each other within analytical uncertainty. These anomalous samples do not affect the overall trend, however. The ${ }^{87} \mathrm{Sr} /{ }^{86} \mathrm{Sr}$ values in the pore-water samples were lower (the $\mathrm{Sr}$ in the pore water was less radiogenic) than those in the shell material collected nearest the sediment from which the pore water was extracted.

\section{Relation of $\mathrm{Sr}$ Concentration to Pore-Water Geochemistry}

Concentrations of $\mathrm{Sr}$ in the 14 pore-water samples from the lower confining unit and the clay-silt in the upper part of the Atlantic City 800-ft sand correlate strongly with pore-water concentrations of Ca, $\mathrm{Mg}, \mathrm{Na}$, and $\mathrm{SO}_{4}$ (Spearman rank correlation coefficients +0.99 , $+1.00,+0.97$, and +0.91 , respectively). The linear trend of the relation between the pore-water concentrations of $\mathrm{Sr}$ and $\mathrm{Ca}$ in these samples is illustrated by the solid symbols in Figure 6 . The molar ratio of $\mathrm{Sr}$ to $\mathrm{Ca}$ is $\sim 0.00435$ (range $0.00401-0.00477$ ), a value greater than that typical of ground water but less than that of seawater. The molar ratio of $\mathrm{Sr}$ to $\mathrm{Ca}$ in the pore water is in equilibrium in an open hydrologic environment with that in a precipitating calcite phase that contains $\sim 400-700 \mathrm{ppm}$ of $\mathrm{Sr}$ and a dissolving low-Sr aragonite 


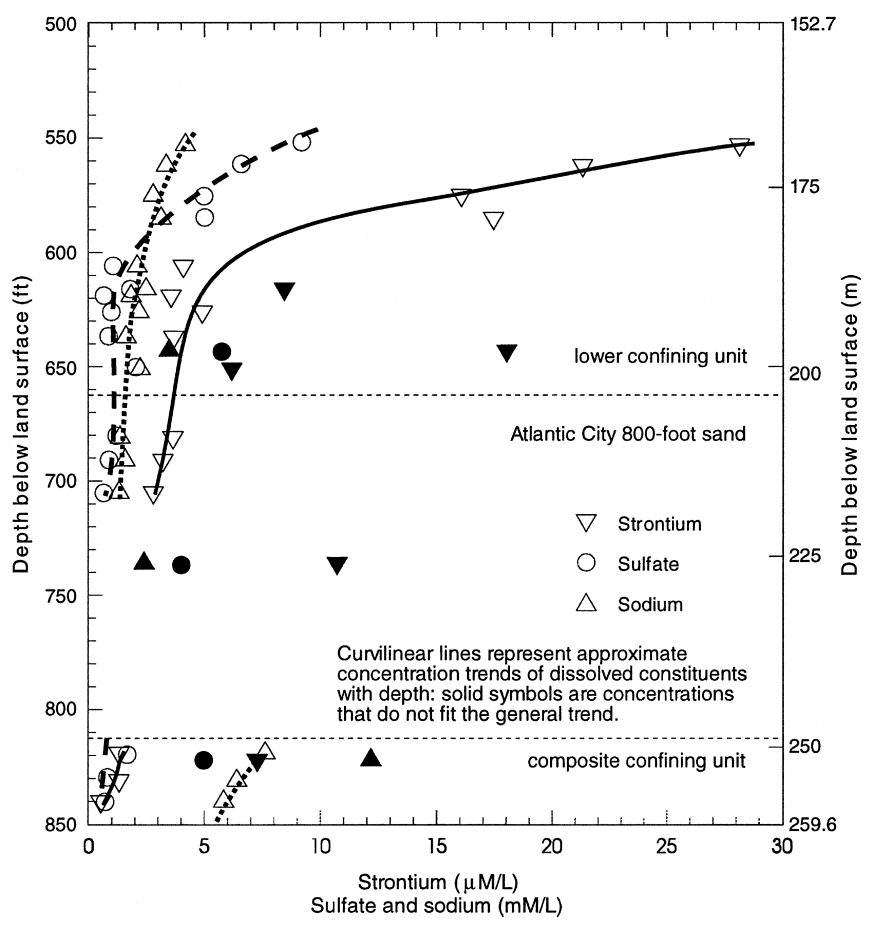

Figure 4. Variation in concentrations of strontium, sulfate, and sodium in pore water with depth below land surface, lower Miocene Kirkwood Formation, Leg 150X Atlantic City borehole.

phase that contains $\sim 1000-4000$ ppm of $\mathrm{Sr}$ (Kinsman, 1969). The relatively low $\mathrm{Sr}$ concentration of the aragonitic phase is typical of mollusks (Lowenstam, 1963). The precipitation of calcite with a much lower $\mathrm{Sr}$ content than that of the dissolving aragonite results in an increase in the molar ratio of $\mathrm{Sr}$ to $\mathrm{Ca}$ in the pore water relative to this ratio in typical mollusk shells (Fig. 6). Many of the pore-water samples are saturated or slightly supersaturated with respect to calcite (Table 2), indicating that calcite may precipitate from the solution. In general, the more highly mineralized pore-water samples, especially those from the uppermost part of both the lower and composite confining units, are the most likely to be saturated or slightly supersaturated with respect to calcite. The samples were undersaturated with respect to aragonite; therefore, dissolution of aragonitic shell materi$\mathrm{al}$, the source of the dissolved $\mathrm{Ca}$ and $\mathrm{Sr}$, is likely an ongoing chemical process. The nearly uniform linear molar ratio of $\mathrm{Sr}$ to $\mathrm{Ca}$ in these samples indicates dissolution of one or two mineral phases (one likely being the mollusk shells), which contain these two elements in fixed proportions, coupled with the precipitation of a Sr-bearing mineral (calcite) that also contains these two elements in a fixed proportion. The differences in pore-water concentrations of $\mathrm{Sr}$ and $\mathrm{Ca}$ from sample to sample indicate differences in the local chemical environment, most likely the availability of dissolving shell material, the carbonate ion, and $\mathrm{pH}$. The latter two characteristics are controlled partly by the varying rates of vertical and horizontal flow and of other chemical reactions, such as metabolization of organic matter by bacteria, in each stratigraphic horizon. Substantially higher Sr concentrations in pore water from marine sediment than those found in this study have been attributed to dissolution of aragonitic shell material (Elderfield and Gieskes, 1982; Manheim et al., 1973).

The nearly linear trend of the relation between concentrations of $\mathrm{SO}_{4}$ and $\mathrm{Ca}$ in the 14 pore-water samples from the lower confining unit and the clay-silt in the upper part of the Atlantic City 800-foot sand is illustrated by the open symbols in Figure 6. Unlike the molar ratio of $\mathrm{Sr}$ to $\mathrm{Ca}$ in these samples, which is exceedingly uniform, the molar ratio of $\mathrm{SO}_{4}$ to $\mathrm{Ca}$ increases slightly with increasing concentra- tions of both $\mathrm{Ca}$ and $\mathrm{SO}_{4}$. The molar ratio of $\mathrm{SO}_{4}$ to $\mathrm{Ca}$ ranges from 0.74 to 1.47 in pore-water samples whose specific conductance is less than $1,000 \mu \mathrm{S} / \mathrm{cm}$, but ranges from 1.25 to 1.67 in samples whose specific conductance is more than $1,000 \mu \mathrm{S} / \mathrm{cm}$. Results of linear regression indicate that the molar ratio of $\mathrm{SO}_{4}$ to $\mathrm{Ca}$ is about 1.04 for pore water with a specific conductance of $500 \mu \mathrm{S} / \mathrm{cm}$ and about 1.56 for pore water with a specific conductance of $2,200 \mu \mathrm{S} / \mathrm{cm}$. This slight increase in the ratio of the concentration of $\mathrm{SO}_{4}$ to that of $\mathrm{Ca}$ (Fig. 6) may indicate that, as the water becomes increasingly mineralized, concentrations of (or the rate of increase in) $\mathrm{Ca}$ and $\mathrm{Sr}$ in solution are fixed, possibly as a result of equilibrium of the mineralized solution with calcite. The concentration of $\mathrm{SO}_{4}$, however, continues to increase strongly because equilibrium of the solution with gypsum has not yet been attained. This result is consistent with the observation that the most mineralized solutions are saturated with respect to calcite. It is also possible, however, that some other chemical process, such as ion exchange, is partly responsible for limiting the rate of increase of $\mathrm{Sr}$ and $\mathrm{Ca}$ concentrations in the most mineralized samples; evidence for ion exchange is discussed below. Understanding of the chemical processes that control the relation between dissolved $\mathrm{Ca}$ and $\mathrm{SO}_{4}$ would be facilitated if the source of the dissolved $\mathrm{SO}_{4}$ were known. Various possible sources of $\mathrm{SO}_{4}$ in pore water from clay-silt confining units in the Atlantic Coastal Plain have been proposed, but the data collected to date are inadequate to definitively determine the source (Chapelle and McMahon, 1991; Pucci et al., 1992; Pucci et al., Chapter 24, this volume).

The composition of the pore-water samples from the composite confining unit is likely strongly affected by ion exchange, as indicated by the high ratio of the concentrations of $\mathrm{SO}_{4}$ to $\mathrm{Ca}$ (Fig. 6), $\mathrm{Na}$ to $\mathrm{Cl}$ (Fig. 7), $\mathrm{Cl}$ to $\mathrm{Sr}$ (Fig. 7), $\mathrm{Na}$ to $\mathrm{Ca}$, and $\mathrm{Na}$ to $\mathrm{Sr}$ in these samples compared with that in samples from the lower confining unit and the clay-silt sediments from the top of the Atlantic City 800-foot sand. The likelihood of a strong effect on solution chemistry as a result of ion exchange is supported by the molar ratio of $\mathrm{SO}_{4}$ to $\mathrm{Ca}$, which exceeds 4 (range 4.07-6.10) in each of the four pore-water samples from the composite confining unit, whereas the value of this ratio does not exceed 1.7 in the 14 pore-water samples from the aquifer and the overlying lower confining unit (Fig. 6). The molar ratio of $\mathrm{Na}$ to $\mathrm{Cl}$ was much higher in pore-water samples from the composite confining unit (range 2.82-6.26) than in samples from the two overlying units (range 0.96-2.49) (Fig. 7). The molar ratio of $\mathrm{Na}$ to $\mathrm{Cl}$ was highest in the samples in which Na concentrations were greatest, indicating a significant source of $\mathrm{Na}$ other than residual seawater or connate water. The source of this $\mathrm{Na}$ is likely exchangeable $\mathrm{Na}$ in the clay-silt. The molar ratio of $\mathrm{Na}$ to $\mathrm{Cl}$ was slightly greater than 1 in all but two of the 14 samples from the lower confining unit and the claysilt sediments at the top of the Atlantic City 800-ft sand; the exceptions are Samples 14 and 15 from the upper part of the Atlantic City 800 -ft sand (Fig. 7). This result indicates a possible minor source of exchangeable $\mathrm{Na}$ in the clay-silt sediments of the lower confining unit, as well as in the composite confining unit. The molar ratios of $\mathrm{Sr}$ and $\mathrm{Ca}$ to $\mathrm{Na}$ in the pore-water samples from the composite confining unit (range 0.00009-0.0006 and 0.025-0.078, respectively) were one-tenth or less of those in the lower confining unit and the clay-silt sediments in the Atlantic City $800-\mathrm{ft}$ sand (range 0.00190.0067 and $0.44-1.54$, respectively). The molar ratio of $\mathrm{Sr}$ to $\mathrm{Cl}$ in the composite confining unit (range 0.00026-0.00374) is much lower than that in the lower confining unit (range 0.00187-0.01116; Fig. 7). Lastly, the molar ratio of $\mathrm{Sr}$ to $\mathrm{Ca}$ in two of the pore-water samples from the composite confining unit exceeds 0.005 (maximum 0.0076), whereas no sample from the lower confining unit has a molar ratio of $\mathrm{Sr}$ to $\mathrm{Ca}$ greater than this value. Exchange substrates are more selective for $\mathrm{Ca}$ than $\mathrm{Sr}$; therefore, pore water strongly affected by ion exchange is expected to have a higher Sr-to-Ca molar ratio than pore water that is affected only slightly or not at all. The molar ratios indicate that the composition of the pore-water samples from the composite confining unit are likely affected by ion exchange. Other possible 


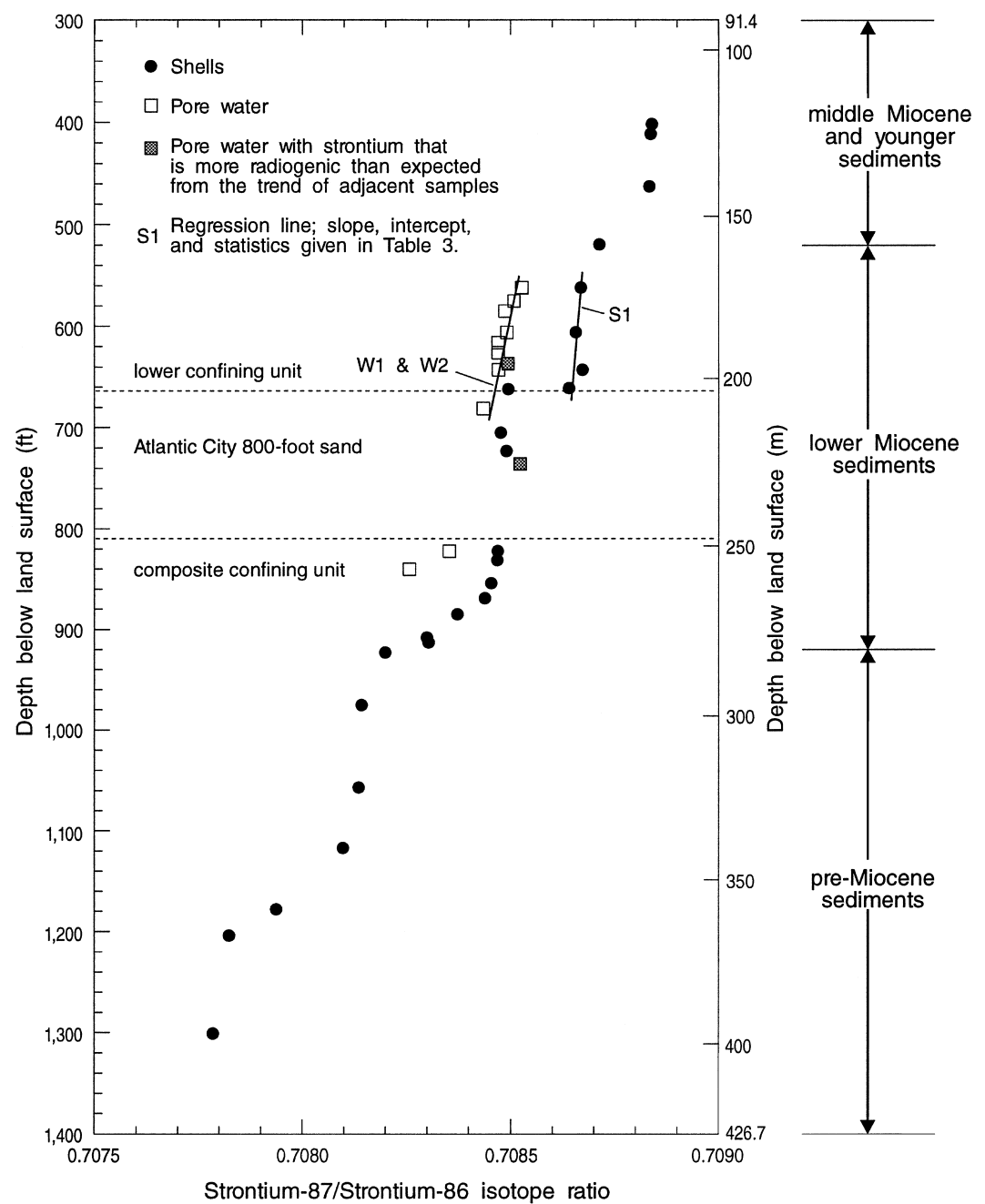

Figure $5 .{ }^{87} \mathrm{Sr} /{ }^{86} \mathrm{Sr}$ values in shells from Eocene to Pleistocene sediments and ${ }^{87} \mathrm{Sr} /{ }^{86} \mathrm{Sr}$ values in pore water from the lower Miocene Kirkwood Formation as a function of depth, Leg 150X Atlantic City borehole $\left({ }^{87} \mathrm{Sr} /{ }^{86} \mathrm{Sr}\right.$ values in shells from Miller et al., 1994). explanations for the variable Sr-to-Ca molar ratio in pore water from the composite confining unit include the precipitation of an extremely pure, Sr-free calcite mineral phase; the presence of aragonitic shells whose $\mathrm{Sr}$ content varies greatly with depth; and slower flow rates in the composite confining unit than in the shallower strata, resulting in nonuniform shell dissolution (Kinsman, 1969). These possibilities cannot be evaluated without additional $\mathrm{Sr}$-isotope data from shell material, carbonate cement, or other Sr-bearing minerals. The chemical composition of the pore water collected to date, however, indicates that several chemical processes likely affect the concentration of dissolved $\mathrm{Sr}$.

\section{Relation of ${ }^{87} \mathrm{Sr} /{ }^{86} \mathrm{Sr}$ Values in Pore Water and Shell Material to Depth and Sr Concentration}

The ${ }^{87} \mathrm{Sr} /{ }^{86} \mathrm{Sr}$ values in the 12 pore-water samples for which this ratio was determined are inversely correlated with depth; this correlation $(r=-0.72)$ is also statistically significant when only the 10 pore-water samples from the lower confining unit and the Atlantic City 800-ft sand are considered (Fig. 5). The slope of the regression line representing the rate of decrease of the ${ }^{87} \mathrm{Sr} /{ }^{86} \mathrm{Sr}$ values in shells (four samples) with depth is approximately twice that of the regression line representing the rate of decrease of the ${ }^{87} \mathrm{Sr} /{ }^{86} \mathrm{Sr}$ values in pore water (eight samples) with depth in the lower confining unit (Table 3; Fig. 5).

The slope of a line representing the decrease in the ${ }^{87} \mathrm{Sr} /{ }^{86} \mathrm{Sr}$ values of shells in the lower part of the Kirkwood Formation with depth should be steep but uniform, because the rate of increase of the ${ }^{87} \mathrm{Sr} /$
${ }^{86} \mathrm{Sr}$ value in seawater through time was nearly uniform and very rapid in the early Miocene Epoch when the sediments were deposited (Oslick et al., 1994; Sugarman et al., 1993; Faure, 1982). Therefore, the slope of the regression line is affected only by changes in sedimentation rates during the early Miocene, a time of rapid but variable sedimentation in the New Jersey Coastal Plain (Sugarman et al., 1993); it is not affected by changes in the rate of increase of the ${ }^{87} \mathrm{Sr} /$ ${ }^{86} \mathrm{Sr}$ value in seawater through time, as is the case for sediments deposited in the middle Miocene and other epochs. The sedimentation rate is assumed to have increased greatly beginning with the deposition of the Atlantic City 800-ft sand; the rate of deposition likely was slower when the clay-silt confining units were deposited (Sugarman et al., 1993). The sudden increase in deposition rate significantly affects the slope of the best-fit line that describes the relation of the ${ }^{87} \mathrm{Sr} /{ }^{86} \mathrm{Sr}$ values in shell material with depth in the lower part of the Kirkwood Formation; hence, only the four shell samples from the lower confining unit were considered for regression analysis.

The difference in the rate of change of the Sr-isotope ratios with depth for the pore-water samples and the shell material from the lower confining unit was not statistically significant (Table 3) despite the apparent difference in the slopes of the respective best-fit lines (Fig. 5). The slopes, recalculated and compared by using standardized data, were not significantly different at the $95 \%$ confidence level (Dowdy and Wearden, 1983). Confidence in the slope of all the regression lines, however, is strongly limited by the small data set.

The Sr-isotope ratios in the pore water correlated only weakly with the inverse of the pore-water concentrations of $\mathrm{Sr}$, and a statistically significant regression line could not be fit to the data. This result 


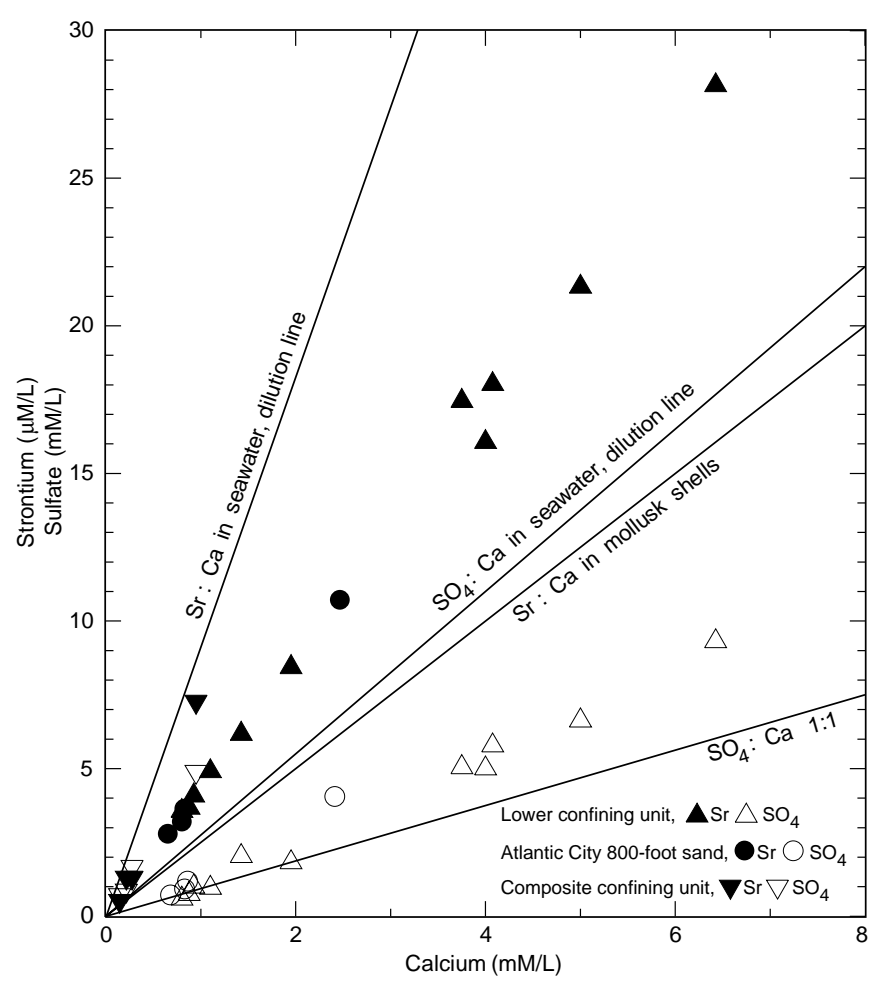

Figure 6. Concentrations of strontium and sulfate as a function of calcium concentration in pore water, lower Miocene Kirkwood Formation, Leg 150X Atlantic City borehole.

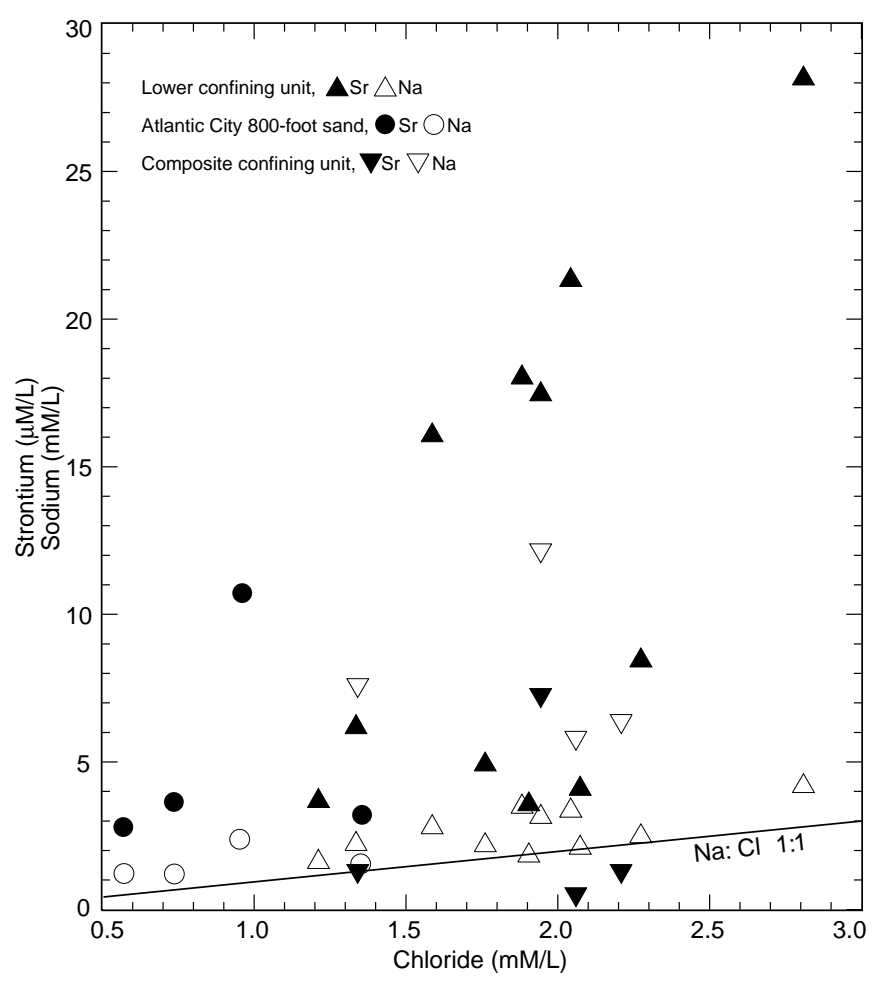

Figure 7. Concentrations of strontium and sodium as a function of chloride concentration in pore water, lower Miocene Kirkwood Formation, Leg 150X Atlantic City borehole. indicates that the pore water cannot readily be described in terms of a simple two-component mixture by using the Sr-concentration data.

\section{DISCUSSION}

\section{Source of $\mathrm{Sr}$}

The ${ }^{87} \mathrm{Sr} /{ }^{86} \mathrm{Sr}$ values in the pore-water samples can be used to determine the likely source(s) of $\mathrm{Sr}$ and the amount of interaction of pore water with carbonate minerals in shells and with silicate minerals in the sediment matrix. The ${ }^{87} \mathrm{Sr} /{ }^{86} \mathrm{Sr}$ values in the detrital silicate minerals in the lower part of the Kirkwood Formation, derived from the nearby continental source area, and in secondary clay minerals in the fine-grained sediment are assumed, on the basis of ${ }^{87} \mathrm{Sr} /{ }^{86} \mathrm{Sr}$ values determined for similar sediments by Dasch (1969), Biscaye (1972), Nardone and Faure (1978), and Elderfield and Gieskes (1982), to be greater than the ${ }^{87} \mathrm{Sr} /{ }^{86} \mathrm{Sr}$ values in the marine shells. Minimal or no contribution of $\mathrm{Sr}$ enriched in the radiogenic ${ }^{87} \mathrm{Sr}$ isotope to the pore water from primary or secondary silicate minerals is indicated in the pore-water samples; such a contribution would result in ${ }^{87} \mathrm{Sr} /{ }^{86} \mathrm{Sr}$ values that are greater than those observed in adjoining carbonate-shell material. Aragonitic shell material contains $\mathrm{Sr}$ in concentrations that are much higher than those found in typical silicate minerals; furthermore, the extreme solubility of aragonite can result in pore water with high concentrations of $\mathrm{Sr}$ because of partial dissolution of the aragonitic shells. Concentrations of $\mathrm{Sr}$ in pore water from fine-grained marine sediments containing abundant shell material have been reported by Elderfield and Gieskes (1982) and Manheim et al. (1973) to be typically as high as $600 \mu \mathrm{M} / \mathrm{L}$; a maximum of $1,200 \mu \mathrm{M} / \mathrm{L}$ was reported by Elderfield and Gieskes (1982). Therefore, it would be reasonable to conclude that the dissolved $\mathrm{Sr}$ in the pore water in the lower part of the Kirkwood Formation is derived primarily from aragonitic shell material in the adjacent sediment, except that the ${ }^{87} \mathrm{Sr} /{ }^{86} \mathrm{Sr}$ values in the pore-water samples are lower than those in the shell material collected nearest the associated pore-water samples.

One possible source of $\mathrm{Sr}$ in pore water with a ${ }^{87} \mathrm{Sr} /{ }^{86} \mathrm{Sr}$ value lower than that of the aragonitic shell material at the same or similar depth is silicate minerals that have a low ${ }^{87} \mathrm{Sr} /{ }^{86} \mathrm{Sr}$ value, such as plagioclase in glass shards derived from basaltic volcanism. Pore water from deep-sea sediment interbedded with basaltic debris and glass shards or basalt flows has been shown to contain $\mathrm{Sr}$ with a lower ${ }^{87} \mathrm{Sr} /$ ${ }^{86} \mathrm{Sr}$ value than either contemporaneous seawater or the calcite in the sediment (Elderfield and Gieskes, 1982; Hawkesworth and Elderfield, 1978). Neither basaltic debris and glass shards nor Sr-bearing, $\mathrm{Ca}$-rich plagioclase from basalts, except for minor amounts of $\mathrm{Na}$ rich plagioclase near the base, is known to be present in the Kirkwood Formation (Isphording, 1970). Because Kirkwood Formation sediments were deposited in the New Jersey Coastal Plain as a result of tectonic uplift of continental crust and subsequent erosion (Owens, 1985; Sugarman et al., 1993) rather than volcanism, $\mathrm{Sr}$ in the pore water cannot be derived from basaltic, Ca-rich plagioclase. Another possible source of $\mathrm{Sr}$ is a $\mathrm{SO}_{4}$-bearing evaporite mineral such as gypsum; however, such a mineral is unlikely to be present in Kirkwood Formation sediments, which are marine in origin. No primary deposits of gypsum have been found in sediment from other boreholes drilled in the New Jersey Coastal Plain (Pucci et al., 1992).

The only known sources of $\mathrm{Sr}$ with isotope ratios lower than those in the shell material in the lower confining unit are shell material near the base of the lower confining unit, shell material from the composite confining unit near the base of the Kirkwood Formation, and shell material from pre-Miocene stratigraphic units (Fig. 5). Similarly, the only known sources of $\mathrm{Sr}$ with isotope ratios lower than those in the shell material in the composite confining unit are shell material from the base of the Kirkwood Formation and shell material from preMiocene stratigraphic units (Fig. 5). Within each of these confining 
Table 3. Linear correlation of ${ }^{87} \mathrm{Sr} /{ }^{86} \mathrm{Sr}$ values in pore water and shell material with depth, lower Miocene Kirkwood Formation, Atlantic City borehole, and results of the Student's $t$-test to determine whether the slopes of the linear regressions in the lower confining unit are statistically the same or different.

\begin{tabular}{|c|c|c|c|c|c|c|c|c|c|}
\hline Dependent Variable & $\begin{array}{c}\text { Regression } \\
\text { number }\end{array}$ & $\begin{array}{l}\text { Number of } \\
\text { samples }\end{array}$ & $\begin{array}{l}\text { Depth below } \\
\text { land surface }(\mathrm{ft})\end{array}$ & Slope & Intercept & F-ratio & $\begin{array}{c}\text { Adjusted } \\
\mathrm{R}^{2}\end{array}$ & $t$-value & $\begin{array}{l}\text { Difference } \\
\text { in slopes }\end{array}$ \\
\hline $\begin{array}{l}{ }^{87} \mathrm{Sr} / 86 \mathrm{Sr} \text {, shells } \\
{ }^{87} \mathrm{Sr} / 86 \mathrm{Sr} \text {, pore water }\end{array}$ & $\begin{array}{l}\text { S1 } \\
\text { W1 }\end{array}$ & $\begin{array}{l}4 \\
8\end{array}$ & $\begin{array}{l}559-661 \\
562-643\end{array}$ & $\begin{array}{l}2.29 \times 10^{-7} \\
4.95 \times 10^{-7}\end{array}$ & $\begin{array}{l}0.708800 \\
0.708794\end{array}$ & $\begin{array}{r}3.14 \\
13.76\end{array}$ & $\begin{array}{l}0.26 \\
0.61\end{array}$ & $\begin{array}{l}1.321 \\
1.321\end{array}$ & $\begin{array}{l}\text { None } \\
\text { None }\end{array}$ \\
\hline${ }^{87} \mathrm{Sr} /{ }^{86} \mathrm{Sr}$, pore water & W2 & 9 & $562-681$ & $5.05 \times 10^{-7}$ & 0.708807 & 48.37 & 0.78 & No test & No test \\
\hline${ }^{87} \mathrm{Sr} /{ }^{86} \mathrm{Sr}$, pore water & w3 & 12 & $562-840$ & $6.63 \times 10^{-7}$ & 0.708918 & 44.99 & 0.68 & No test & No test \\
\hline
\end{tabular}

Notes: Depth below land surface was treated as a negative number in the regression equations. F-ratio $=$ mean square due to regression/mean square due to residual variation. $\mathrm{R}^{2}=$ coefficient of determination for the regression; indicates how well the regression fits the data.

units, the ${ }^{87} \mathrm{Sr} /{ }^{86} \mathrm{Sr}$ value in shell material at the base is lower than that in shell material near the top.

\section{Processes Affecting the Distribution of Sr Isotopes}

The presence in the pore water of Sr from shells from depths greater than those from which the pore-water samples were collected could result from several processes. These processes include upward movement of Sr-bearing shells through the reworking of older shell material, and upward movement of Sr itself through diffusion and advection.

\section{Reworking of Older Shell Material}

Shells may have been reworked and redeposited in sediment younger than that in which the shells originally were deposited. Nardone and Faure (1978) document the presence of reworked Cretaceous to Oligocene coccolith shells in Quaternary sediments from the Black Sea; ${ }^{87} \mathrm{Sr} /{ }^{86} \mathrm{Sr}$ values in these older shells are lower than those in the indigenous contemporaneous species. Dissolution of similar reworked shells in the Kirkwood Formation, if present, could result in pore-water ${ }^{87} \mathrm{Sr} /{ }^{86} \mathrm{Sr}$ values that are lower than those in the adjoining contemporaneous mollusk shells. The presence of reworked preMiocene ${ }^{87} \mathrm{Sr}$-depleted mollusk or other type of shell has not been demonstrated in the Kirkwood Formation, however. The shells generally are broken but, as noted by Sugarman et al. (1993), this feature may represent transport of the shells during storms into deep water before final deposition. Furthermore, no evidence is available to show that other fossil species of diatoms or foraminifers were reworked (Miller et al., 1994). Lastly, such reworked shells would have to be homogeneously distributed throughout the sediment column of the Kirkwood Formation to produce the observed smooth decrease in ${ }^{87} \mathrm{Sr} /{ }^{86} \mathrm{Sr}$ values with depth; the likelihood of such a distribution is small, especially because the sedimentation rate was variable in early the Miocene (Sugarman et al., 1993).

\section{Upward Movement of $\mathrm{Sr}$}

Alternative processes that explain the low ${ }^{87} \mathrm{Sr} /{ }^{86} \mathrm{Sr}$ value in pore water, relative to that of adjoining shell material include, those that facilitate the upward movement of $\mathrm{Sr}$ itself. $\mathrm{Sr}$ in pore water that is less radiogenic than that in the adjacent shell material may, in fact, reflect upward movement of Sr-bearing pore water into the clay-silts by advective transport through geologic time from deeper sediments. Pore water at the base of the Kirkwood Formation was in contact with shell material containing $\mathrm{Sr}$ with a lower ${ }^{87} \mathrm{Sr} /{ }^{86} \mathrm{Sr}$ value than that in the lower confining unit. Alternatively, upward diffusive transport of $\mathrm{Sr}$ from depth also could result in a decrease in the ${ }^{87} \mathrm{Sr} /{ }^{86} \mathrm{Sr}$ value in pore water relative to that in the adjacent shell material through time.

Upward movement of water through the Coastal Plain sediments near the coast is consistent with the results of a computer simulation of prepumping ground-water flow in the New Jersey Coastal Plain
(Martin, in press), which indicate that water from pre-Miocene strata moves upward through Miocene and younger strata before it discharges to the Atlantic Ocean (Fig. 2). Upward diffusion of $\mathrm{Sr}$ through the pore water in the clay-silt sediments is not consistent, however, with the observed concentration gradient of $\mathrm{Sr}$ in the lower confining unit. The concentration of $\mathrm{Sr}$ in pore water is greatest near the top of the lower confining unit and is lowest near its base (Fig. 4); diffusion of $\mathrm{Sr}$ as a result of the $\mathrm{Sr}$-concentration gradient would therefore be expected to be downward.

\section{Diffusion}

Upward diffusion of Sr may be possible from sediments containing pore water with large concentrations of Sr to overlying strata containing pore water with small concentrations of Sr. For example, sediments at $643 \mathrm{ft}(196 \mathrm{~m})$, near the base of the lower confining unit, contain Sr-rich pore water (Sample 9, $18.0 \mu \mathrm{M} / \mathrm{L}$ ), whereas the immediately overlying sediments (Sample 8, $637 \mathrm{ft}$ [194 m]) contain Srpoor pore water $(3.67 \mu \mathrm{M} / \mathrm{L})$, making upward diffusion of Sr likely. Even here, however, the ${ }^{87} \mathrm{Sr} /{ }^{86} \mathrm{Sr}$ value in the pore water at $643 \mathrm{ft}$ is substantially lower (0.708471) than that in shell material (0.708672) in adjacent strata. This result indicates that, even in the Sr-rich pore water near the base of the lower confining unit, the source of the dissolved $\mathrm{Sr}$ must be shell material from a greater depth than that from which the pore-water sample was collected. Furthermore, both $\mathrm{Sr}$ concentrations and the concentration gradient decrease toward the aquifer, making upward diffusion of $\mathrm{Sr}$ with a low ${ }^{87} \mathrm{Sr} /{ }^{86} \mathrm{Sr}$ value unlikely. The potential for $\mathrm{Sr}$ diffusion downward from $643 \mathrm{ft}$ cannot be adequately evaluated because the ${ }^{87} \mathrm{Sr} /{ }^{86} \mathrm{Sr}$ value was not determined for the pore-water sample from $651 \mathrm{ft}$ (198.4 m; Sample 10), where downward diffusion of $\mathrm{Sr}$ (based on the observed Sr-concentration gradient) could be expected to affect the Sr-isotope ratio. Local downward diffusion of $\mathrm{Sr}$ in the lower confining unit cannot be ruled out as a mechanism that affects the ${ }^{87} \mathrm{Sr} /{ }^{86} \mathrm{Sr}$ profile with depth, especially in sections where individual pore-water samples have $\mathrm{Sr}$ concentrations and ${ }^{87} \mathrm{Sr} /{ }^{86} \mathrm{Sr}$ values that differ strongly from the expected value based on the general trend of the $\mathrm{Sr}$ concentration or isotopic ratio with depth (Fig. 5). The frequency of sample collection is insufficient, however, to evaluate this hypothesis. It is also possible that the $\mathrm{Sr}$-concentration gradient has changed through time resulting in upward diffusion of $\mathrm{Sr}$, but this hypothesis cannot be tested with available data.

The limited number of pore-water samples collected from the composite confining unit preclude the reconstruction of the Srconcentration gradient through it. The concentration of $\mathrm{Sr}$ in the composite confining unit was greatest in Sample 16 (822 ft [251 m]), whereas the concentration was lowest in Sample 18 (840 ft [256.5 $\mathrm{m}])$. This Sr-concentration distribution indicates the possibility of upward diffusion of $\mathrm{Sr}$ toward the Atlantic City 800-ft sand above $822 \mathrm{ft}(251 \mathrm{~m})$ and downward diffusion of Sr below this depth. As in the lower confining unit, the observed Sr-concentration gradient does not indicate that upward diffusion of $\mathrm{Sr}$ is the dominant process 
controlling the Sr-isotope ratio in pore water, except perhaps in a few selected intervals.

\section{Advection}

Upward advective transport of $\mathrm{Sr}$ can be considered at two scales: internal transport within an individual hydrogeologic unit, and crossformational transport across several units. Internal transport of $\mathrm{Sr}$ from shell material at the base of a given confining unit toward the top can occur if the $\mathrm{Sr}$ is dissolved from the shell material by the pore water and at least some of this $\mathrm{Sr}$ is advected along the flow path without being removed immediately from solution by ion exchange or some other process, such as coprecipitation with calcite or adsorption. For the internal transport of $\mathrm{Sr}$ to affect the $\mathrm{Sr}$ isotope ratio in pore water near the top of a confining unit, the upward flux of Sr must be sufficiently large that a significant portion of the $\mathrm{Sr}$ in the pore water at a given point must have been derived originally from shell material near the base of the confining unit. The appreciable concentration of $\mathrm{Sr}$ in pore water in the lower confining unit indicates that $\mathrm{Sr}$ generally remains in solution after being dissolved; thus, internal advection of $\mathrm{Sr}$ is likely to occur. The concentration of $\mathrm{Sr}$ in pore water in the composite confining unit, however, is smaller than that in the lower confining unit and is limited by cation exchange. Although internal advection of $\mathrm{Sr}$ may occur, it may take longer to advect the same mass of $\mathrm{Sr}$ the same vertical distance in the composite confining unit than in the lower confining unit. Therefore, in a given period of time, internal transport of Sr likely has a smaller effect on the Srisotope ratio in pore water in the composite confining unit than in the lower confining unit.

If upward advection of $\mathrm{Sr}$ from the base to the top of each confining unit occurred, the ${ }^{87} \mathrm{Sr} /{ }^{86} \mathrm{Sr}$ values in pore water would be most similar to those in adjacent shell material at or near the base of each confining unit and least similar to those at the top of the unit. If it is assumed that the interbedded clay-silt unit at the top of the Atlantic City 800 -ft sand is hydrologically the base of the lower confining unit, the ${ }^{87} \mathrm{Sr} /{ }^{86} \mathrm{Sr}$ values determined for pore water and adjacent shell material in the lower confining unit, in general, do show such a trend, but with many anomalies. The ${ }^{87} \mathrm{Sr} /{ }^{86} \mathrm{Sr}$ value in a pore-water sample from the interbedded clay-silt unit at the top of the Atlantic City 800$\mathrm{ft}$ sand (Sample 11, $681 \mathrm{ft}[207.6 \mathrm{~m}], 0.708434$ ) is close to that in shell material collected $\sim 14 \mathrm{ft}(4.3 \mathrm{~m})$ below the pore-water sample (0.708476). The ${ }^{87} \mathrm{Sr} /{ }^{86} \mathrm{Sr}$ value in the pore-water sample from sediment at $643 \mathrm{ft}(196.4 \mathrm{~m})$, near the base of the lower confining unit (Sample 9, 0.708471), is, however, significantly lower than that $(0.708672)$ in the shell material collected from the same depth. The ${ }^{87} \mathrm{Sr} /{ }^{86} \mathrm{Sr}$ value in this pore-water sample is similar to that in shell material from the clay-silt unit at the top of the Atlantic City 800-ft sand (0.708476). Similarly, the pore-water samples from the middle and upper parts of the lower confining unit all contain $\mathrm{Sr}$ with isotopic ratios much lower than those in the adjacent shell material. These results indicate that the shell material at the top of the Atlantic City $800-\mathrm{ft}$ sand and the base of the lower confining unit is likely an important source of the $\mathrm{Sr}$ in pore water at shallower depths in the lower confining unit. The rates of change with depth (slopes) of the ${ }^{87} \mathrm{Sr} /{ }^{86} \mathrm{Sr}$ values determined for the pore-water and shell-material samples from the lower confining unit were not significantly different, however, indicating that the ratios do not diverge toward the top of the unit. Although the ${ }^{87} \mathrm{Sr} /{ }^{86} \mathrm{Sr}$ values in pore water generally increase slowly upward from the base of the lower confining unit, the ratios in some depth intervals are nearly uniform over vertical distances of 20$30 \mathrm{ft}(6.1-9.1 \mathrm{~m})$. For example, the ratio is identical or nearly identical in pore-water samples from 616 and $626 \mathrm{ft}$ (187.8 and $190.8 \mathrm{~m}$; Samples 6 and 7-B) and in those from 585 and $606 \mathrm{ft}(178.3$ and $184.7 \mathrm{~m}$; Samples 4 and 5). The physical significance of these results is not known. Because the sampling frequency was low, especially near the base and the top of the unit, and because the difference in the slopes of the relations between the ${ }^{87} \mathrm{Sr} /{ }^{86} \mathrm{Sr}$ values in pore water and shell material with depth was not statistically significant, the results cannot be considered conclusive evidence of internal transport through the confining unit.

The Sr-concentration and isotope-ratio data indicate that the pore water is not a simple two-component mixture; nevertheless, the concept of a simple two-component mixing curve can be used to crudely approximate the proportions of $\mathrm{Sr}$ in a pore-water sample that are derived from adjacent shell material and from shell material at the base of the unit. This simple approximation was made for Sample 2 from $562 \mathrm{ft}(171.3 \mathrm{~m})$ near the top of the lower confining unit. For simplification, it was assumed that the $\mathrm{Sr}$ concentrations in the two solutions being mixed were equal. (Because this assumption is false, the computed proportions of mixing are only gross estimates.) The simplified mixing equation, without the $\mathrm{Sr}$-concentration terms, is

$$
\left({ }^{87} \mathrm{Sr} /{ }^{86} \mathrm{Sr}\right)_{\mathrm{M}}=f\left({ }^{87} \mathrm{Sr} /{ }^{86} \mathrm{Sr}\right)_{\mathrm{A}}+(1-f)\left({ }^{87} \mathrm{Sr} /{ }^{86} \mathrm{Sr}\right)_{\mathrm{B}},
$$

where $\left({ }^{87} \mathrm{Sr} /{ }^{86} \mathrm{Sr}\right)_{\mathrm{A}},\left({ }^{87} \mathrm{Sr} /{ }^{86} \mathrm{Sr}\right)_{\mathrm{B}}$, and $\left({ }^{87} \mathrm{Sr} /{ }^{86} \mathrm{Sr}\right)_{\mathrm{M}}$ are the $\mathrm{Sr}$ isotope ratios in water that is in equilibrium with adjacent shell material, in water that is in equilibrium with shell material at the base of the confining unit, and in the pore-water sample that represents the hypothetical mixture of these two end members, respectively; and $f$ is the mixing parameter that indicates the proportion of $\mathrm{Sr}$ in the mixture (the pore-water sample) that originates from water that is in equilibrium with the adjacent shell material. The equation was solved for the mixing parameter, $f$. It was assumed that $\mathrm{Sr}$ in isotopic equilibrium with the shell material at $643 \mathrm{ft}(196 \mathrm{~m})$ had migrated $81 \mathrm{ft}(24.7 \mathrm{~m})$ upward to the depth from which pore-water Sample 2 was collected. The parameters used are defined in Table 2 as follows: $\left({ }^{87} \mathrm{Sr} /{ }^{86} \mathrm{Sr}\right)_{\mathrm{A}}=$ $0.708668,\left({ }^{87} \mathrm{Sr} /{ }^{86} \mathrm{Sr}\right)_{\mathrm{B}}=0.708494$, and $\left({ }^{87} \mathrm{Sr} /{ }^{86} \mathrm{Sr}\right)_{\mathrm{M}}=0.708527$. The computed mixing parameter of 0.15 indicates that, even near the top of the lower confining unit, a large proportion of the $\mathrm{Sr}$ in the pore water $(85 \%)$ could have originated from shell material near the base of the unit.

For large amounts of Sr to have been advectively transported from the base of the lower confining unit to near the top, many pore volumes of water must have passed through the confining unit. The residence time of a particle of water in a confining unit (the time required for the particle to move advectively from the base to the top of the unit) can be computed by using a modified version of Darcy's Law. Although some of the terms required for the computation are unknown for the lower confining unit, they are known for the upper confining unit, which lies above the Rio Grande water-bearing zone and is similar in thickness and lithology to the lower confining unit. The residence time for the upper confining unit was computed by using the formula

$$
\mathrm{t}=\mathrm{dAn} / \mathrm{Q}
$$

where $t$ is the residence time, $\mathrm{d}$ is the thickness of the upper confining unit at Atlantic City ( 104 ft [31.7 m]), A is the area of the model cell (Martin, in press) that represents Atlantic City $\left(16.2 \times 10^{6}\right.$ $\mathrm{m}^{2}$ ), $\mathrm{n}$ is the porosity (estimated minimum value of 0.35 ), and $\mathrm{Q}$ is the flow of water through the top of the model cell $\left(1.71 \times 10^{-4} \mathrm{~m}^{3} / \mathrm{s}\right.$ [Martin, in press]). The computed residence time in the upper confining unit is $33.3 \mathrm{ka}$, which is assumed to be a reasonable estimate for the lower confining unit as well. If hydrologic conditions are assumed to have been uniform through time, this result indicates that 33 pore volumes of water passed through the confining unit in the last 1 m.y., or that about 400 pore volumes passed through the unit since the emergence of the New Jersey Coastal Plain at the end of the middle Miocene Epoch (Meisler et al., 1985), when current ground-water-flow patterns were established. Depending on the concentration of $\mathrm{Sr}$ in the pore water through time, a large mass of $\mathrm{Sr}$ may have moved upward from near the base of the unit by advection; in fact, the mass of Sr that was transferred likely was sufficient to affect ${ }^{87} \mathrm{Sr} /{ }^{86} \mathrm{Sr}$ in present-day pore water near the top of the lower confining unit. Although long-term sea level has not varied signifi- 
cantly since the end of the middle Miocene Epoch (Kominz, 1984), short-term eustatic lowering of up to $120 \mathrm{~m}$ (Fairbanks, 1989) has occurred many times since then. High stands of sea level during interglacial periods would have reduced ground-water flow, whereas low stands of sea level during glacial periods would have increased it. It is not clear how these short-term changes would have affected cumulative ground-water flow through this time.

For large-scale cross-formational transport of Sr to be sufficient to affect the $\mathrm{Sr}$ isotope ratio in pore water in an adjacent unit, the upward flux of $\mathrm{Sr}$ must be sufficiently large that a significant portion of the $\mathrm{Sr}$ within the aquifer must be derived from the underlying confining unit. Therefore, dilution of the upward-leaking pore water must be sufficiently small that the amount of Sr contributed to the aquifer is not negligible relative to the amount of $\mathrm{Sr}$ in the water in the aquifer. No data on the ${ }^{87} \mathrm{Sr} /{ }^{86} \mathrm{Sr}$ values of $\mathrm{Sr}$ dissolved in the aquifer are available. Sr concentrations in water of the Atlantic City 800-ft sand north of Atlantic City in south-central New Jersey are low (0.38-0.71 $\mu \mathrm{M} / \mathrm{L}$, median $0.46 \mu \mathrm{M} / \mathrm{L}$ [Harriman and Sargent, 1985]). Sr concentrations in pore water from the composite confining unit underlying the Atlantic City 800-ft sand at the site of the current study were as high as $7.27 \mu \mathrm{M} / \mathrm{L}$ (Sample 16; Table 2), however. Because the $\mathrm{Sr}$ concentrations in the aquifer are low, leakage of even small amounts of confining-unit pore water could add significant amounts of $\mathrm{Sr}$.

Transmissivity of the Atlantic City $800-\mathrm{ft}$ sand is high (860$13,000 \mathrm{ft}^{2} / \mathrm{d} ; 10,000 \mathrm{ft}^{2} / \mathrm{d}$ at Atlantic City); the vertical leakance of the underlying composite confining unit is low-most likely about $1 \times$ $10^{-7}(\mathrm{ft} / \mathrm{d}$ )/ft at Atlantic City (see Martin, in press, table 8 and figs. 62 and 71). Therefore, vertical flow of water into the aquifer is much less than the horizontal flow of water in the aquifer, and confining-unit pore water that leaks into the aquifer is probably significantly diluted. Water budgets for individual model cells (Martin, in press) were used to estimate the dilution of pore water leaking upward from the composite confining unit through the Atlantic City 800 -ft sand to the lower confining unit near Atlantic City. Calculations indicate a dilution factor (horizontal flow in the aquifer to vertical flow from the confining unit) of 20:1. With this dilution factor, the contribution of $\mathrm{Sr}$ from the composite confining unit to the aquifer is probably sufficient for the $\mathrm{Sr}$-isotope ratio in water in the aquifer to remain similar to that in the pore water from the composite confining unit, because the pore water may contain 10 to 20 times as much $\mathrm{Sr}$ as the water in the aquifer. Hence, water entering the lower confining unit from the aquifer may have a Sr-isotope ratio similar to that in the pore water from the composite confining unit. This would not be true, however, if the $\mathrm{Sr}$ dissolved from the aquifer material were significantly more radiogenic than the $\mathrm{Sr}$ in the upward-leaking pore water; no data are available to evaluate this possibility. Sr-isotope data for shallow ground water in the Great Artesian Basin of Australia reported by Collerson et al. (1988) indicate, however, that the time scale at which the ${ }^{87} \mathrm{Sr} /$ ${ }^{86} \mathrm{Sr}$ values in shallow ground water in siliciclastic sediment become strongly radiogenic is about $10^{6} \mathrm{yr}$. Because the residence time of water in the Atlantic City 800-ft sand at Atlantic City is less than $10^{6} \mathrm{yr}$, the ${ }^{87} \mathrm{Sr} /{ }^{86} \mathrm{Sr}$ value in the water is not expected to be controlled by radiogenic Sr derived from dissolution of Sr-bearing silicate minerals, such as K-feldspar. Another limitation of the calculation is the fact that flow paths in the aquifer are horizontal, which results in horizontal displacement of $\mathrm{Sr}$ from where it enters the aquifer to where it leaves the aquifer. Therefore, samples collected at the base of the lower confining unit are not on the same flow path as samples collected from the top of the composite confining unit. Whether the ${ }^{87} \mathrm{Sr} /{ }^{86} \mathrm{Sr}$ value varies horizontally or not in the confining units is unknown.

Adjacent samples of pore water in the lower confining unit commonly have great differences in concentrations of $\mathrm{Sr}$ but about the same ${ }^{87} \mathrm{Sr} /{ }^{86} \mathrm{Sr}$. For example, Samples 4 and $5(585 \mathrm{ft}[178.3 \mathrm{~m}]$ and $606 \mathrm{ft}$ [184.7 m], respectively) have a large difference in Sr concentration (17.45 and $4.09 \mu \mathrm{M} / \mathrm{L}$, respectively), but have nearly identical ${ }^{87} \mathrm{Sr} /{ }^{86} \mathrm{Sr}$ values $(0.708486$ and 0.708491 , respectively). This result cannot be explained with the simple two-component mixing model described above. If upward-migrating pore water deposited carbon- ate crusts or micritic carbonate matrix throughout geologic time, the secondary calcites could contribute $\mathrm{Sr}$ to pore water by partial redissolution as a result of subsequent minor decreases in pore-water $\mathrm{pH}$ or dissolved- $\mathrm{CO}_{2}$ concentration. Such secondary calcite crusts bear the Sr-isotopic signature of the pore water from which the crusts were precipitated, which may differ from that of the unaltered shell material they coat. Bishop et al. (1994) demonstrated that the Sr-isotope ratio of secondary calcite cement in an area underlain by carbonate rocks is significantly different from that of primary calcite in the same formation. Popp et al. (1986) found that even diagenetically altered shell material can retain the original ${ }^{87} \mathrm{Sr} /{ }^{86} \mathrm{Sr}$ values of the seawater at the time of deposition, but that ${ }^{87} \mathrm{Sr} /{ }^{86} \mathrm{Sr}$ values in diagenetically altered micritic matrix surrounding these shells are similar to those in the pore water from which the micrite was deposited. Partial redissolution of a secondary crust in the sediment of the Kirkwood Formation could contribute abundant $\mathrm{Sr}$ to the pore water, while the ${ }^{87} \mathrm{Sr} /{ }^{86} \mathrm{Sr}$-isotope value remains lower than that of the adjoining shell materials. No micritic cement or crusts were observed in hand samples of the sediment; however, geochemical calculations show that the pore water is saturated with respect to calcite in many of the sediment layers (Table 2). Therefore, the presence of finely disseminated secondary calcite cement is thermodynamically possible.

If the distribution of ${ }^{87} \mathrm{Sr}$ and ${ }^{86} \mathrm{Sr}$ in pore water from the confining units can be used as an indicator of flow through the New Jersey Coastal Plain sediments, it may be useful in the corroboration of the calibration of large-scale flow models, such as that of Martin (in press). First, however, the rates of the mechanisms that cause $\mathrm{Sr}$ isotope ratios in the pore water to differ from those in the shell material (advection of $\mathrm{Sr}$ as well as geochemical reactions that affect concentrations of dissolved $\mathrm{Sr}$ ) must be quantified.

\section{CONCLUSIONS}

The evolution of water quality in confined aquifers such as the Atlantic City 800 -ft sand in the New Jersey Coastal Plain may be affected by leakage of pore water from the surrounding silty confining units; therefore, we examined the distribution and sources of solutes in the pore water in the confining units. Relations of Sr concentrations to those of other chemical constituents and the distribution of the ${ }^{87} \mathrm{Sr} /{ }^{86} \mathrm{Sr}$ value were used to determine possible sources of the solutes and identify the physical and chemical processes that may affect their distribution in the confining units above and below the Atlantic City $800-\mathrm{ft}$ sand. The following conclusions were reached:

1. Concentrations of $\mathrm{Sr}$ in pore water in clay-silt sediments above the Atlantic City 800-ft sand varied with depth; they were highest at the top of the unit. Concentrations of $\mathrm{Sr}$ in pore water correlated strongly with concentrations of $\mathrm{Ca}, \mathrm{Mg}, \mathrm{Na}$, and $\mathrm{SO}_{4}$. The distribution of concentrations of $\mathrm{Sr}$ and correlated constituents indicates that diffusion of these constituents must be downward into the aquifer.

2. Concentrations of $\mathrm{Sr}$ and $\mathrm{Ca}$ in pore water from the clay-silt sediments below the sand were lower than those in the claysilt sediments above it, possibly as a result, in part, of cationexchange processes.

3. $\mathrm{The}{ }^{87} \mathrm{Sr} /{ }^{86} \mathrm{Sr}$ values in the pore water were lower than those in the adjacent shell material at all depths but one. The ${ }^{87} \mathrm{Sr} /{ }^{86} \mathrm{Sr}$ values in the pore water appeared to decrease more rapidly with depth than those in the shell material, but this difference was not statistically significant. Statistical analysis was limited by the small sample size.

4. The only known source of $\mathrm{Sr}$ with isotope ratios lower than those in shell material in sediment from the lower Miocene Kirkwood Formation is shell material from sediment found at greater depth, including pre-Miocene stratigraphic units. Therefore, the Sr-isotope ratio in the pore water may result from upward movement of water into or through the clay-silt sediments through geologic time. 


\section{ACKNOWLEDGMENTS}

This research was conducted by the U.S. Geological Survey, Lafayette College, and Rutgers University in cooperation with the New Jersey Department of Environmental Protection under NSF Grant No. EAR93-04022 and EAR94-17108 and New Jersey Department of Environmental Protection Agreement No. NJ9305601. The authors gratefully acknowledge Dr. Kenneth G. Miller of Rutgers University for his efforts in obtaining access to samples; Mr. Theodore Ehlke of the U.S. Geological Survey and Marco Morais and Nebby Idris of Lafayette College for assistance in sample collection; and Dr. Peter Sugarman of the New Jersey Department of Environmental Protection for determination of Sr-isotope ratios in the shells. The authors also thank Dr. Julia Barringer and Dr. Peter Sugarman for their critical review of this manuscript.

\section{REFERENCES}

Barton, G.J., Storck, D.A., and Paulachok, G.N., 1993. Records of wells, exploratory boreholes, and ground-water quality, Atlantic County and vicinity, New Jersey. U.S. Geol. Surv. Open-File Rep., 92-631.

Biscaye, P.E., 1972. Strontium isotope composition and sediment transport in the Rio de la Plata Estuary. Mem.-Geol. Soc. Am., 133:349-357.

Bishop, P.K., Smalley, P.C., Emery, D., and Dickson, J.A.D., 1994. Strontium isotopes as indicators of the dissolving phase in a carbonate aquifer: implications for ${ }^{14} \mathrm{C}$ dating of groundwater. J. Hydrol., 154:301-321.

Chapelle, F.H., and McMahon, P.B., 1991. Geochemistry of dissolved inorganic carbon in a Coastal Plain aquifer, 1 . Sulfate from confining beds as an oxidant in microbial $\mathrm{CO}_{2}$ production. J. Hydrol., 127: 85-108.

Collerson, K.D., Ullman, W.J., and Torgensen, T., 1988. Ground waters with unradiogenic ${ }^{87} \mathrm{Sr} /{ }^{86} \mathrm{Sr}$ ratios in the Great Artesian Basin, Australia. Geology, 16:59-63.

Dasch, E.J., 1969. Strontium isotopes in weathering profiles, deep-sea sediments, and sedimentary rocks. Geochim. Cosmochim. Acta, 33:15211552.

Dowdy, S.M., and Wearden, S., 1983. Statistics for Research: New York (Wiley).

Elderfield, H., and Gieskes, J.M., 1982. Sr isotopes in interstitial waters of marine sediments from Deep Sea Drilling Project Cores. Nature, 300:493-497.

Fairbanks, R.G., 1989. A 17,000-year glacio-eustatic sea level record: influence of glacial melting rates on the Younger Dryas event and deep-ocean circulation. Nature, 342:637-642.

Faure, G., 1982. The marine-strontium geochronometer. In Odin, G.S. (Ed.), Numerical dating in stratigraphy: New York (Wiley \& Sons), 73-79.

Fisher, R.S., and Stueber, A.M., 1976. Strontium isotopes in selected streams within the Susquehanna River Basin. Water Resour. Res., 12:1061-1068.

Harriman, D.A., and Sargent, B.P., 1985. Ground-water quality in east-central New Jersey, and a plan for sampling networks. U.S. Geol. Surv. Water Res. Invest. Rep., 85-4243.

Hawkesworth, C.J., and Elderfield, H., 1978. The strontium isotopic composition of interstitial waters from sites 245 and 336 of the Deep Sea Drilling Project. Earth Planet. Sci. Lett., 40:423-432.

Isphording, W.C., 1970. Petrology, stratigraphy, and re-definition of the Kirkwood Formation (Miocene) of New Jersey. J. Sediment. Petrol., 40:986-997

Kharaka, Y.K., Gunter, W.D., Aggarwall, P.K., Perkins, E.H., and DeBraal, J.D., 1988. SOLMINEQ: a computer program for geochemical modelling of water rock interactions. U.S. Geol. Surv. Water Res. Invest. Rep., 884277.

Kinsman, D.J.J., 1969. Interpretation of $\mathrm{Sr}^{+2}$ concentrations in carbonate minerals and rocks. Soc. Econ. Paleontol. Mineral., 39:486-508.

Kominz, M.A., 1984. Oceanic ridge volumes and sea-level change: an error analysis. In Schlee, J.S. (Ed.), Interregional Unconformities and Hydrocarbon Accumulation. AAPG Mem., 36:109-127.

Lowenstam, H.A., 1963. Sr/Ca ratio of skeletal aragonites from the recent marine biota at Palau and from fossil gastropods. In Craig, Harmen, Miller, S.L., and Wasserburg, G.J. (Eds.), Isotopic and Cosmic Chemistry: Amsterdam (North Holland Publ. Co.), 114-132.
Manheim, F.T., Sayles, F.L., and Waterman, L.S., 1973. Interstitial water studies on small core samples, Deep Sea Drilling Project: Leg 10. In Worzel, J.L., Bryant, W., et al. (Eds.), Init. Repts. DSDP, 10: Washington, D.C. (U.S. Government Printing Office), 615-624.

Martin, M., in press. Ground-water flow in the New Jersey Coastal Plain. U.S. Geol. Surv. Prof. Pap., 1404-H.

Meisler, H., Leahy, P.P., and Knobel, L.L., 1985. Effect of eustatic sea-level changes on saltwater-freshwater relations in the Northern Atlantic Coastal Plain. U.S. Geol. Surv. Water Supply Pap., 2255.

Miller, K.G., Browning, J.B., Liu, C., Sugarman, P., Kent, D.V., Van Fossen, M., Queen, D., Goss, M., Gwynn, D., Mullikin, L., Feigenson, M.D., Aubry, M.-P., Burckle, L.D., 1994. Atlantic City site report. In Miller, K.G., et al., Proc. ODP, Init. Repts. 150X: College Station, TX (Ocean Drilling Program), 35-55.

Miller, K.G., and Sugarman, P.J., 1995. Correlating Miocene sequences in onshore New Jersey boreholes (ODP Leg 150X) with global $\delta^{18} \mathrm{O}$ and Maryland outcrops. Geology, 23:747-750.

Nardone, C.D., and Faure, G., 1978. A study of sedimentation at DSDP Hole 379A, Black Sea, based on the isotopic composition of strontium. In Ross, D.A., and Neprochnov, Y.P. (Eds.), Init. Repts. DSDP, 42 (Part 2): Washington, D.C. (U.S. Government Printing Office), 607-615.

Oslick, J.S., Miller, K.G., and Feigenson, M.D., 1994. Oligocene-Miocene strontium isotopes: stratigraphic revisions and correlations to an inferred glacioeustatic record. Paleoceanography, 9:427-443.

Owens, J.P., 1985. Kirkwood Formation and Cohansey Sand of New Jersey: Age and spatial relation to Chesapeake Group of Virginia and Maryland. AAPG Bull., 69:1445. (Abstract)

Peterman, Z.E., Hedge, C.E., and Tourtelot, H.A., 1970. Isotopic composition of strontium in sea water throughout Phanerozoic time. Geochim. Cosmochim. Acta, 34:105-120.

Popp, B.N., Podosek, F.A., Brannon, J.C., Anderson, T.F., and Pier, J., 1986. ${ }^{87} \mathrm{Sr} /{ }^{86} \mathrm{Sr}$ ratios in Permo-Carboniferous sea water from the analyses of well-preserved brachiopod shells. Geochim. Cosmochim. Acta, 50:13211328.

Pucci, A.A., Jr., Ehlke, T.A., and Owens, J.P., 1992. Confining unit effects on water quality in the New Jersey Coastal Plain. Ground Water, 30:415427.

Stanley, K.O., and Faure, G., 1979. Isotopic composition and sources of strontium in sandstone cements: the High Plains sequence of Wyoming and Nebraska. J. Sediment. Petrol., 49:45-54.

Stueber, A.M., Baldwin, A.D., Curtis, J.B., Jr., Pushkar, P., and Steele, J.D., 1975. Geochemistry of strontium in the Scioto River drainage basin, Ohio. Geol. Soc. Am. Bull., 86:892-896.

Stueber, A.M., Pushkar, P., and Hetherington, E.A., 1984. A strontium isotopic study of Smackover brines and associated solids, southern Arkansas. Geochim. Cosmochim. Acta, 48:1637-1649.

Sugarman, P.J., Miller, K.G., Owens, J.P., and Feigenson, M.D., 1993. Strontium-isotope and sequence stratigraphy of the Miocene Kirkwood Formation, southern New Jersey. Geol. Soc. Am. Bull., 105:423-436.

Sunwall, M.T., and Pushkar, P., 1979. The isotopic composition of strontium in brines from petroleum fields of southeastern Ohio. Chem. Geol., 24:189-197.

Szabo, Z., 1984. An isotopic study of the origin of carbonate cement in the Berea Sandstone, Athens County, Ohio [M.S. thesis]. Ohio State Univ., Columbus, Ohio.

Szabo, Z., and Faure, G., 1987. Isotopic studies of carbonate cements and provenance dating of feldspar in basin analysis: the Berea Sandstones of Ohio, U.S.A. In Rodriguez-Clemente, R., and Tardy, Y. (Eds.), Geochemistry of Mineral Formation in the Earth Surface: Madrid, Spain (Consejo Superior de Investigaciones Cientificas), 51-65.

Veizer, J., 1983. Chemical diagenesis of carbonates: theory and application of trace element technique. In Arthur, M.A., Anderson, T.F., Kaplan, I.R., Veizer, J., and Land, L.S., (Eds.) Stable Isotopes in Sedimentary Geology. SEPM Short Course No. 10, 3-100.

Zapecza, O.S., 1989. Hydrogeologic framework of the New Jersey Coastal Plain. Geol. Surv. Prof. Pap. U.S., 1404-B.

Date of initial receipt: 30 January 1996

Date of acceptance: 16 December 1996

Ms 150XSR-322 